\title{
A Systematic Review on Secondary Metabolites of Paecilomyces Species: Chemical Diversity and Biological Activity
}

\author{
Authors \\ Xiu-Qi Li ${ }^{1,2 *}$, Kuo Xu ${ }^{1 *(\mathbb{D})}$, Xin-Min Liu ${ }^{1}$, Peng Zhang ${ }^{1(\mathbb{D})}$ \\ Affiliations \\ 1 Tobacco Research Institute of Chinese Academy of Agri- \\ cultural Sciences, Qingdao, People's Republic of China \\ 2 Graduate School of Chinese Academy of Agricultural \\ Sciences, Beijing, China
}

Key words

Paecilomyces, secondary metabolites, chemical diversity, biological activity

received March 25, 2020

revised May 28, 2020

accepted May 30, 2020

Bibliography

DOI https://doi.org/10.1055/a-1196-1906

published online July 9, 2020 | Planta Med 2020; 86: 805-821

(c) Georg Thieme Verlag KG Stuttgart · New York I

ISSN 0032-0943

Correspondence

Prof. Peng Zhang

Tobacco Research Institute of Chinese Academy

of Agricultural Sciences

Keyuanjing the Fourth Road 11, 266101 Qingdao, China

Phone: + 8653266715079 , Fax: + 8653266715079

zhangpeng@caas.cn

\author{
Correspondence \\ Prof. Xin-Min Liu \\ Tobacco Research Institute of Chinese Academy \\ of Agricultural Sciences \\ Keyuanjing the Fourth Road 11, Qingdao 266101, China \\ Phone: + 8653266715079 , Fax: + 8653266715079 \\ liuxinmin@caas.cn
}

Supporting information available online at

http://www.thieme-connect.de/products

\section{ABSTRACT}

Fungi are well known for their ability to synthesize secondary metabolites, which have proven to be a rich resource for exploring lead compounds with medicinal and/or agricultural importance. The genera Aspergillus, Penicillium, and Talaromyces are the most widely studied fungal groups, from which a plethora of bioactive metabolites have been characterized. However, relatively little attention has been paid to the genus Paecilomyces, which has been reported to possess great potential for its application as a biocontrol agent. Meanwhile, a wide structural array of metabolites with attractive bioactivities has been reported from this genus. This review attempts to provide a comprehensive overview of Paecilomyces species, with emphasis on the chemical diversity and relevant biological activities of these metabolic products. Herein, a total of 148 compounds and 80 references are cited in this review, which is expected to be beneficial for the development of medicines and agrochemicals in the near future.

\section{Introduction}

The hyphomycete genus Paecilomyces was established by Bainier in 1907 [1]. It was characterized as being closely related to Penicillium species but differed in the absence of green colored colonies and the presence of verticillate conidiophores with short cylindrical phialides that taper into long distinct necks [2]. Paecilomyces species are common environmental molds, ubiquitous in soil and composts, and are often associated with the decay of food products. Although some species of Paecilomyces have been implicated as plant, animal (mainly insects), and human pathogens, Paecilomyces species have shown great application potential in industry, agriculture, and medicine. Moreover, several species of Paecilomy- ces have been regarded as important biocontrol agents, including Paecilomyces carneus, Paecilomyces farinosus, Paecilomyces fumosoroseus, and Paecilomyces lilacinus. These findings suggest that Paecilomyces species are a high-value microbial resource, not only for their potential use but also for their ability to produce various bioactive substances.

Filamentous fungi are distributed worldwide and play an important role in human history. The discovery of penicillin, the first broad-spectrum antibiotic agent, from the fungal genus Penicillium was a monument in medical research and has saved count-

* These authors contributed equally to this work. 
less lives. Subsequently, the study of fungi has become a hotspot, as fungi produce secondary metabolites with intriguing structures and potential pharmaceutical applications. The genera Aspergillus, Penicillium, and Talaromyces represent the most widely studied fungal groups, and a plethora of their bioactive metabolites have been characterized [3]. However, relatively little attention has been paid to the genus Paecilomyces.

Several interesting reviews related to various aspects of Paecilomyces species have been published. For example, Mioso et al. reviewed the chemical diversity of the secondary metabolites produced by the fungus Paecilomyces variotii, indicating that $P$. variotii and its active metabolites can provide leading compounds for new drug discoveries [4]. Zimmermann summarized the biology, ecology, and use of Isaria farinosa (formerly Paecilomyces farinosus) and Isaria fumosorosea (formerly $P$. fumosoroseus) as biocontrol agents against pest insects, plant pathogens, and nematodes in the laboratory and the field [5]. Only one review has specifically focused on the metabolites from $P$. variotii and their biological activities [4]. To the best of our knowledge, a comprehensive overview of Paecilomyces species, with an emphasis on the chemical diversity and relevant biological activities of these metabolic products, remains untouched. As part of our ongoing investigations of structurally diverse and biologically active secondary metabolites from P. variotii [6-10], we also performed a detailed and comprehensive literature survey on all Paecilomyces species. The literature search was performed using the combined key words "Paecilomyces" and "secondary metabolites" in the Web of Science Core Collection database, with a previously reported search method [11]. As a result, 80 references closely related to the scope of the review were selected. A total of 148 secondary metabolites isolated from Paecilomyces species were included. Their structures were classified within a biogenetic context as polyketides (macrolides, quinones, anthraquinones, and unsaturated lactones), terpenoids and steroids, peptides, including diketopiperazines, and alkaloids and other nitrogen-containing compounds. Herein, we describe the sources, chemical structures, and bioactivities of the reported compounds from Paecilomyces species with particular emphasis on their potential use as drug lead compounds.

\section{Taxonomy and Biocontrol Application of Paecilomyces Species}

\section{Taxonomy}

Taxonomically, the genus Paecilomyces belongs to the Ascomycota phylum, Eurotiales order, and its teleomorph is suggested to be within the genus Byssochlamys. According to the data from the Index Fungorum database (www.indexfungorum.org), 145 species of Paecilomyces have been reported worldwide. However, the taxonomic classification of this genus remains ill defined. The morphological descriptions of Paecilomyces as well as the delimitation of the genus and its relationship to other genera were published by Samson (1974) [12]. Samson defined the delimitation of the genus Paecilomyces, which was restricted to species with verticillate conidiophores of divergent whorls of branches and phialides [2,12]. Accordingly, the species involved in Paecilomyces were divided into two sections. Section Paecilomyces often contains thermophilic species accompanied by Talaromyces, Byssochlamys, or Thermoascus in the ascigerous state, while section Isarioidea contains those mesophilic species without the ascigerous state, such as Paecilomyces amoeneroseus, P. farinosus, P. fumosoroseus, Paecilomyces javanicus, P. lilacinus, and Paecilomyces tenuipes [13]. However, the taxonomic classification of these fungi was mainly based on their morphological characteristics, which resulted in the construction of unreliable taxonomic systems [14]. Therefore, molecular phylogeny using various DNA markers was applied to unambiguously determine their phylogenetic relationships [2, 13-15].

After several years of research, phylogenetic analysis proved that the genus Paecilomyces is polyphyletic across two ascomycete orders, Eurotiales and Hypocreales [13-15]. Luangsa-ard et al. reported phylogenetic relationships of Paecilomyces sect. Isarioidea species using the $\beta$-tubulin gene and ITS rDNA and found that sect. Paecilomyces is polyphyletic within Hypocreales, while a group designated the Isaria clade was considered to be monophyletic [15]. These findings were also supported by a phylogenetic analysis of the ITS1-5.8S-ITS2 gene sequences [13]. Then, the generic name Isaria was designated and used for species previously assigned to Paecilomyces sect. Isarioidea $[16,17]$. Further studies on the reclassification of the genus Paecilomyces led to the transfer of some species from Paecilomyces sect. Isarioidea into the genus Isaria [5]. Some species previously assigned to Paecilomyces sect. Isarioidea, such as Isaria japonica, Isaria tenuipes, Paecilomyces cicadae, Isaria farinosus, and I. fumosoroseus, are now assigned to the genus Isaria, within the order Hypocreales (Ascomycota) [5] (details are available in Supporting Information).

Herein, we do not obsess too much about the classification status of the genus Paecilomyces, although an in-depth review of the taxonomic revision of the genus Paecilomyces is urgently needed to clarify the phylogenetic relationships. It should be pointed out that, in this review, we focused only on the "true" Paecilomyces species that can be searched with the key word "Paecilomyces" in the Web of Science Core Collection database, ignoring their phylogenetic relationships and the species belonging to the genus Isaria.

\section{Biocontrol Application}

Paecilomyces species possess great application potential in the industrial, agricultural, and pharmaceutical fields. For example, Paecilomyces sinclairii has been reported to possess the capability of producing high yields of natural-sourced red pigments, which have been widely used in the foodstuff, cosmetics, and pharmaceutical industries [18]. P. variotii exhibited excellent phenol degradation performance and can be applied in the treatment of industrial wastewater [19]. Meanwhile, P. variotii was used to convert toxic waste from castor beans into animal feed material and produce tannase and phytase, important enzymes used in agroindustry [20]. However, the most important and valuable applications are probably focused on biological control.

Many of the Paecilomyces species have proven to be highly promising biocontrol agents. P. lilacinus is one of the most widely studied biological control species for plant-parasitic nematodes, 
such as root knot nematodes, cyst nematodes, and citrus nematodes, protecting the root systems of crops and thus increasing productivity [21]. Lara et al. demonstrated that the nematophagous fungus $P$. lilacinus reduced the root-knot nematode Meloidogyne incognita soil and root populations, parasitized the nematode eggs, and increased the tomato yield [22]. Kiewnick and Sikora also reported that the commercial $P$. lilacinus strain 251 provided significant control efficiency of $M$. incognita on tomatoes and suggested that the main activity occurred in soil; thus, a high concentration of conidia was critical for sufficient biocontrol [23]. Yang et al. described an antagonistic effect against oilseed rape rot Sclerotinia sclerotiorum in laboratory and field trials using a new transformant, pt361, derived from the wild strain $P$. lilacinus, indicating that the mutant pt361 of $P$. lilacinus was a novel and promising biocontrol agent for S. sclerotiorum in oilseed rape [24].

Apart from $P$. lilacinus, the saprophytic $P$. fumosoroseus is also well known and used as a whitefly biopesticide. Wraight et al. discovered that $P$. fumosoroseus can infect Bemisia argentifolii nymphs, which resulted in applications for the microbial control of nymphal whiteflies infesting cucurbit crops [25]. Further study revealed that $P$. fumosoroseus can produce highly abundant dipicolinic acid as the active molecular basis responsible for insecticidal activity [26]. Kavková and Čurn discovered that $P$. fumosoroseus significantly suppressed the development and spread of cucumber powdery mildew, suggesting $P$. fumosoroseus as a potential mycoparasite on Sphaerotheca fuliginea [27]. P. fumosoroseus also induced high mortality of Spodoptera exigua, indicating that this fungal strain possessed good potential to develop biopesticides to control beet armyworms [28].

Overall, Paecilomyces species exhibited outstanding performance in biological control and considerable potential applications to develop biopesticides. Thus, chemical investigations of these fungi are particularly needed to reveal their chemical basis.

\section{Chemical Diversity of Secondary Metabolites}

Filamentous fungi have been extensively studied in recent decades, and they have been shown to be an intriguing source of bioactive natural products. The fungal genomes encode a large number of enzymes, including nonribosomal peptide synthetases, polyketide synthases, and terpene synthases, that are responsible for synthesizing secondary metabolites. Consequently, fungi can produce an enormous array of structurally diverse metabolites with a wide range of biological properties, some of which are under consideration as lead compounds in the pharmaceutical and agrochemical arenas. To date, a wide structural array of metabolites with attractive bioactivities have been reported from Paecilomyces species. A total of 148 secondary metabolites isolated from this genus have been classified into four major categories: polyketides, terpenoids and steroids, peptides including diketopiperazines, and alkaloids and other nitrogen-containing compounds.

\section{Polyketides}

Polyketides comprise a large family of structurally diverse molecules biosynthesized by polyketide synthases (PKSs). The main structural types reviewed in this section are macrolides and qui- nones. - Fig. 1 exhibits 25 macrolides characterized from Paecilomyces species, including 19 new compounds. Brefeldin A (1), also named decumbin, cyanein, ascotoxin, or synergisidin, is a 16membered macrolide that has been previously isolated from a number of fungal genera: Alternaria, Ascochyta, Cercospora, Curvularia, Penicillium, and Phyllosticta [29]. Originally, brefeldin A was described as an antifungal, cytotoxic, and cancerostatic antibiotic. Wang et al. first reported the isolation of this cytotoxin from Paecilomyces sp. [30]. Four new $\beta$-resorcylic acid lactones (RALs), named paecilomycins $A(2), B(5), E(6)$, and $F(7)$, and four known congeners, aigilomycin B (3), zeaenol (8), aigialomycin D (9), and aigialospirol (10), were isolated from the mycelial solid culture of Paecilomyces sp. SC0924, which was obtained from a soil sample collected in the Dinghu Mountain Biosphere Reserve, Guangdong, China [31]. RALs are a group of fungal polyketide metabolites possessing a 14-membered lactone ring formed by a side chain with 11 carbons. Compound 4 was the artificial acetonide product of the treatment of 2 with 2,2-dimethoxypropane [31]. Afterwards, the research group obtained another 15 new RALs from the same fungal strain, including paecilomycins $G-I$ (11-13) [32], paecilomycins J-M (14-17) [33], hypothemycin-type paecilomycins N-P (18-20), radicicol-type dechloropochonin I (21), monocillins VI (22) and VII (23), 4'-hydroxymonocillin IV (24), and 4'-methoxymonocillin IV (25) [34]. Among them, RALs showed structural diversity with epoxy, hydroxyl, carbonyl, and other oxygen-containing groups on the macrolide ring. For example, paecilomycins J-M (14-17) possessed an oxygen bridge between $C-2^{\prime}$ and $C-5^{\prime}$ to form a tetrahydrofuran ring [33], while paecilomycins N (18) and $\mathrm{O}$ (19) featured unprecedented 6/11/5 ring systems [34].

Five new anthraquinones, paeciloquinones A-E (26-30) ( $\vee$ Fig. 2), were characterized from the culture broth of the fungus $P$. carneus P-177, which was isolated from a soil sample [35]. Paeciloxanthone (31), a new xanthone, and two known compounds, emodin (32) and chrysophanol (33), were isolated from the extracts of Paecilomyces sp. Trees 1-7 from mangrove saprophytic bark [36]. Saintopin (34) was obtained from Paecilomyces sp. from soil collected at a vineyard in Yamanashi Prefecture, Japan, while UCE1022 (35) was isolated from Paecilomyces UOE1022 from soil collected in Koganei city, Tokyo $[37,38]$. Chemical investigations of the endophytic fungus Paecilomyces sp. (trees 1-7) from mangrove bark led to the identification of a novel dimer chromone with a new carbon skeleton, paecilin $A$ (36), and its monomer paecilin B (37) [39]. The fungus $P$. variotii Bainier, previously isolated from larvae of Dendroctonus ponderosa Hopk. (mountain pine beetle), was antagonistic to Ophiostoma clavigerum. The metabolites produced by $P$. variotii when grown in liquid culture have been studied, and two new $1 \mathrm{H}$-naphtho [2,3-c]pyran-1-ones, semi-viriditoxin (38) and semi-viriditoxic acid (39), were discovered [40]. Cultivation of the marine-derived fungal strain Paecilomyces sp., an endophyte obtained from the saprophytic bark of a mangrove plant, afforded two new paeciloxocins, A (40) and B (41) [41]. Bioassay-guided isolation of advanced glycation end product (AGE) inhibitors from Paecilomyces sp. 3193B resulted in the identification of 4-O-demethylsilvaticol (42) and (-)-mitorubrin (43) [42]. By screening 50 strains of entomopathogenic fungi and rescreening 7 strains of Paecilomyces gunnii, a methanol extract of $P$. gunnii was found to possess 


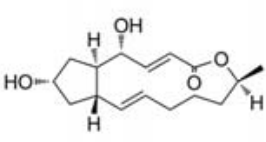<smiles>[R6]Oc1cc(O)c(C(=O)OC(C)C/C=C\CC([R8])C(O)C(O)C=C)c(O)c1</smiles>

$8 \mathrm{R}_{1}=\mathrm{OH}, \mathrm{R}_{2}=\mathrm{CH}_{3}$ $9 \mathrm{R}_{1}=\mathrm{H}, \mathrm{R}_{2}=\mathrm{H}$

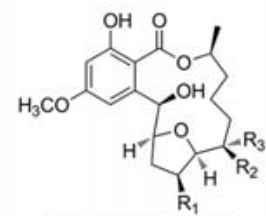

$$
14 \mathrm{R}_{1}=\mathrm{R}_{3}=\mathrm{OH}, \mathrm{R}_{2}=\mathrm{H}
$$
$15 \mathrm{R}_{1}=\mathrm{R}_{3}=\mathrm{H}, \mathrm{R}_{2}=\mathrm{OH}$<smiles>CC(C)OC(=O)c1c(O)cc(O)cc1CC(=O)c1ccccc1</smiles>

21

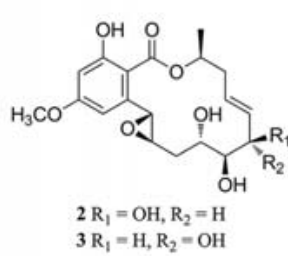<smiles>CCCCCC(O)C(O)C(O)CCCC(C)OC(=O)c1c(C)cc(OC)cc1O</smiles>

10<smiles>COc1cc(O)c(C(=O)OC(C)CC/C=C\C2OC3CC[C@H](O3)[C@H]2O)c(O)c1</smiles>

16

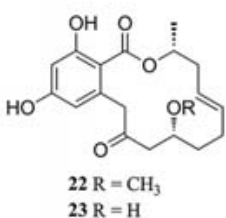<smiles>COc1cc(O)c(C(=O)OC(C)C/C=C\C2OC(C)(C)OC2C(O)CC2CO2)c(O)c1</smiles><smiles>C/C=C/CCC(O)C(O)CCCC(C)OC(=O)c1c(O)cc(OC)cc1O</smiles>

11

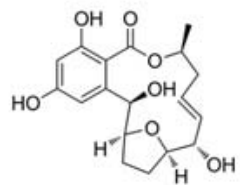

17

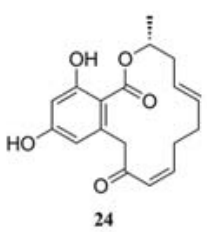<smiles>CCC(O)C1OC(C(O)/C=C\CC(C)OC(=O)c2c(O)cc(OC)cc2O)C(O)CC1O</smiles>

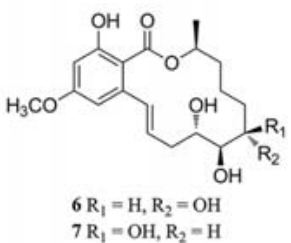<smiles>COC(=O)c1c(O)cc(O)cc1/C=C/C=C\CC1OC2(C)OC(C)C/C=C\C1O2</smiles>

12
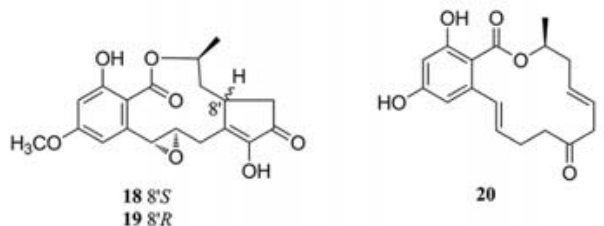

20

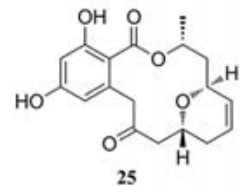

Fig. 1 Macrolides characterized from Paecilomyces species (1-25).

the strongest tyrosinase inhibitory activity. Chemical investigations of this strain resulted in the isolation of three new phenalenones, paecilomycones A-C (44-46) [43]. It should be pointed out that the structure of paecilomycone $\mathrm{C}(45)$ contains an $\mathrm{NH}_{2}$ group. However, herein, we categorize it as a polyketide instead of a nitrogen-containing compound based on the biosynthetic origin of phenalenones. Paeciloside A (47), with a 5-methylorsellinic acid subunit and a pentite, was isolated from cultures of Paecilomyces sp. CAFT156, an endophytic fungus occurring in Enantia chlorantha Oliv (Annonaceae) leaves [44]. Apart from macrolides, the fungus Paecilomyces sp. SC0924 also yielded two new RAL derivatives, paecilomycins $C$ (48) and D (49) [31]. Both compounds possess a dihydroisobenzofuranone ring and a polyhydroxylated linear $C_{10}$ side chain, which are unusual for RALs. Although 48 and 49 are RAL derivatives with similar biogenetic mechanisms, we distinguished them from the macrolide classification because the 14-membered macrolide ring is opened.

A spiroacetal compound named paecilospirone (50) ( $\mathbf{F i g . 3 )}$ was isolated from the marine fungus Paecilomyces sp. collected at Yap Island [45]. Compound 50 was the first example of a unique skeletal structure, spiro[chroman-2,1 $1^{\prime}\left(3^{\prime} H\right)$-isobenzofuran], obtained from natural sources [45]. Then, four closely related dimeric octaketide spiroketals, paeciloketals (51-54), were isolated from the marine fungus $P$. variotii derived from the giant jel- lyfish Nemopilema nomurai [46]. Compounds 51 and 52 contain a benzannulated $[5,6]$-spiroketal moiety, while compounds 53 and 54 possess a $[5,5]$-spiroketal core skeleton. Four new polyketides, paecilocins A-D (55-58), were isolated from the same fungal strain, of which 55-57 contained a longer $\left(C_{8}\right)$ alkyl chain [47]. Two new $\alpha$-pyrones (59 and 60 ) and two new cyclohexenones (61 and 62) were isolated from the whole broth of the fungus P. lilacinus, a strain derived from a marine sponge Petrosia sp. [48]. Interestingly, cyclohexenones have been reported only from the genera Phoma and Alternaria belonging to the family Pleosporaceae (order Pleosporales). This study was the first to isolate these compounds (61 and 62) from the genus Paecilomyces belonging to the family Trichocomaceae (order Eurotiales). Thus, the isolation of the compounds reported herein from far distinct genera may be meaningful for the chemotaxonomic relationships among them [48]. The screening of antitrypanosomal agents from microbial metabolites led to the discovery of four $\alpha$-pyrones (63-66) from Paecilomyces sp. FKI-3573 was collected from a soil sample, of which pyrenocine I (63) was isolated as a new compound [49]. Chemical investigation of the fungus Paecilomyces cateniobliquus YMF1.01799 led to the isolation and identification of four phomalactone-type metabolites (67-70), two of which were new compounds (67 and 68) [50]. The dicyclic spiro compound paecilospirone (71) was isolated as a new antibiotic from 


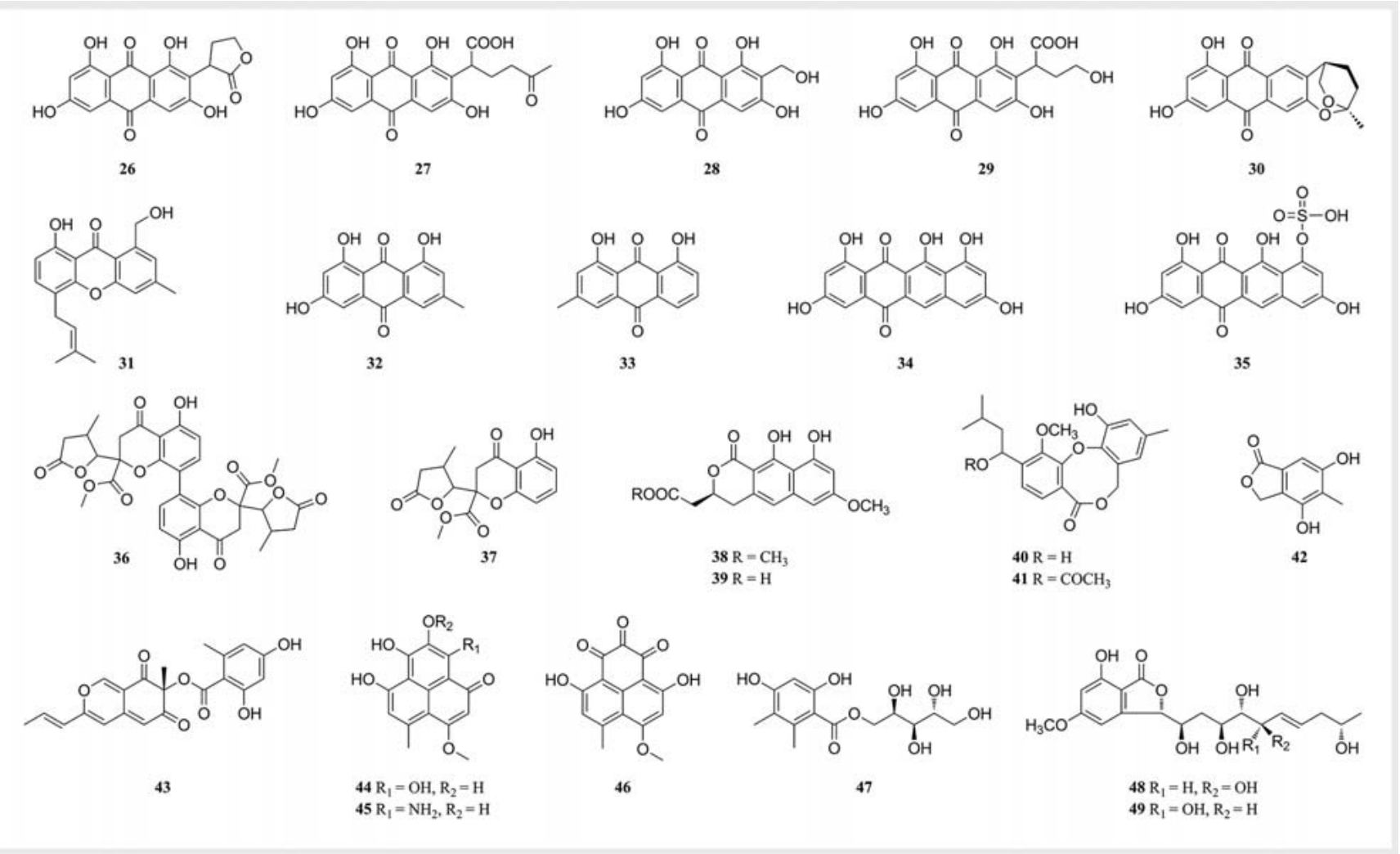

- Fig. 2 Polyketides characterized from Paecilomyces species (26-49).

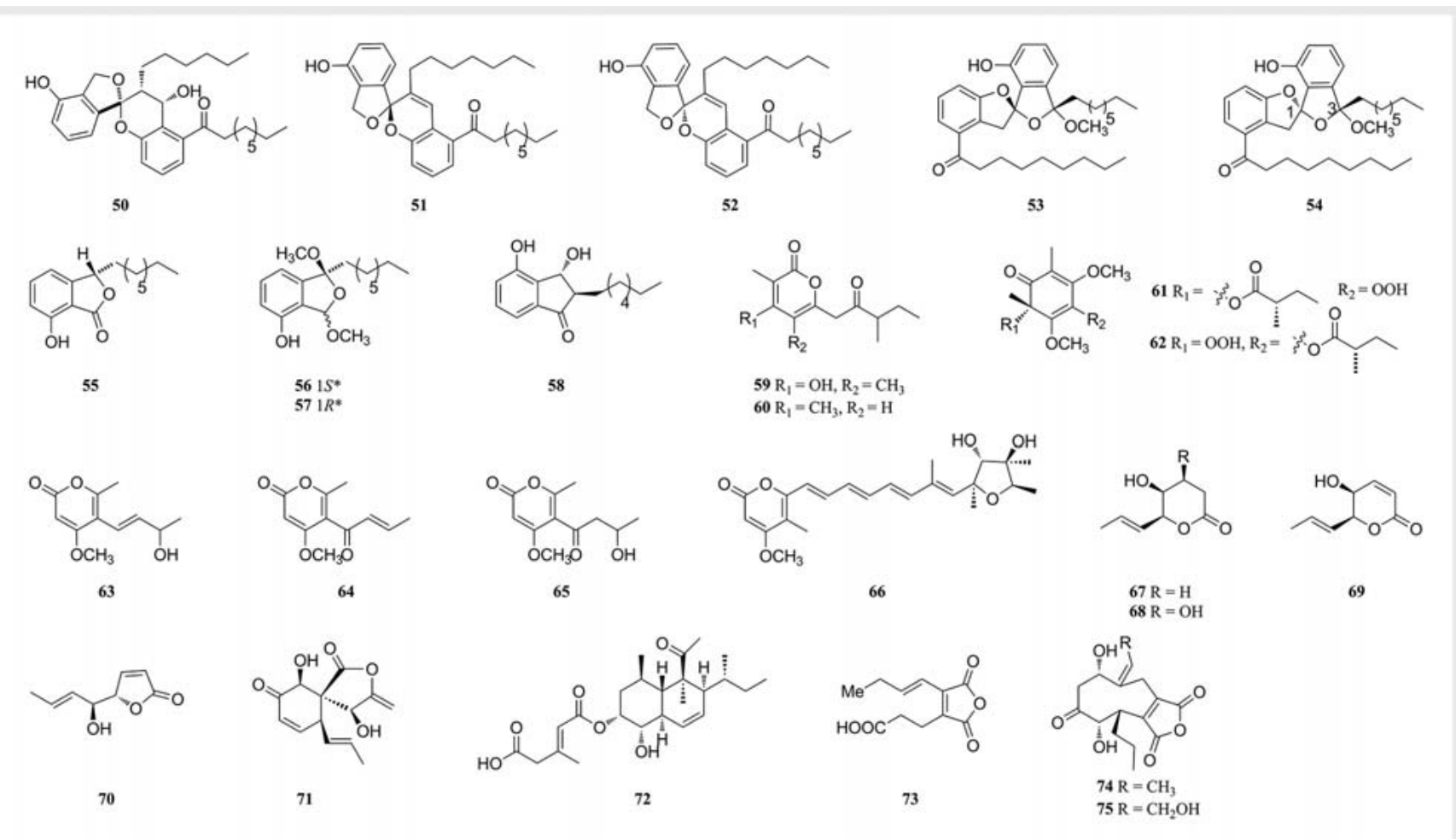

- Fig. 3 Polyketides characterized from Paecilomyces species (Continued) (50-75). 


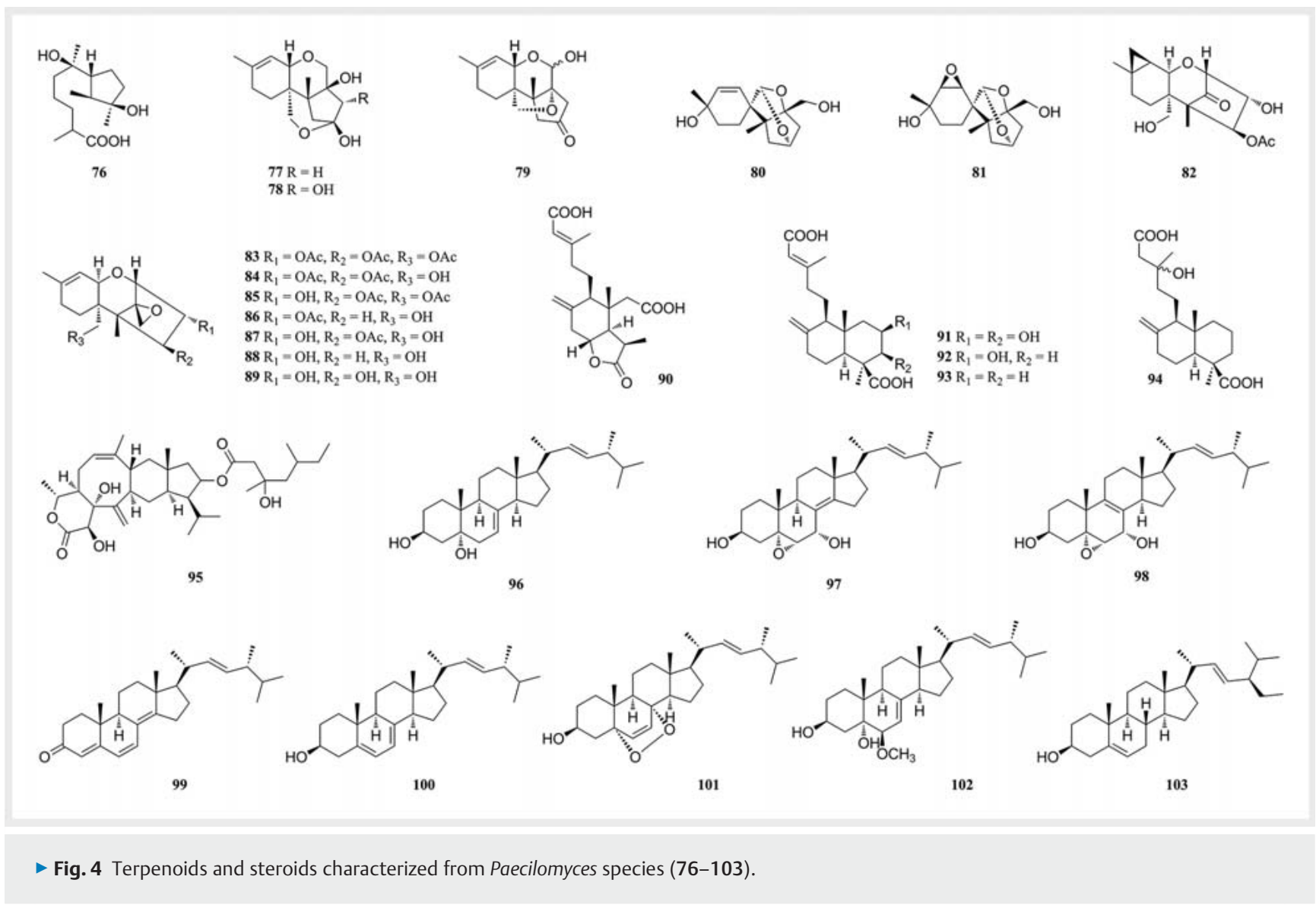

Paecilomyces sp. collected from a soil sample [51]. The saltwater culture of a Paecilomyces cf. javanica isolated from the marine sponge Jaspis cf. Coriacea yielded a new polyketide, deoxynortrichoharzin (72) [52]. A new tricarboxylic acid anhydride (73) was isolated in high yield from $P$. variotii Bain [53]. Shake flask cultures of $P$. variotii produced two phytotoxins, cornexistin (74) and 14hydroxycornexistin (75) [54]. Compound 75 was a new member of the nonadride family with high herbicidal effects.

\section{Terpenoids and steroids}

Catenioblin C (76) ( $\bullet$ Fig. 4), a new sesquiterpenoid, was isolated from the fungus $P$. cateniobliquus YMF1.01799 [5]. P. tenuipes, also known as I. japonica, is a common entomopathogenic fungus used in folk medicine and health foods [55-57]. Cultivating the fruiting bodies of $P$. tenuipes resulted in the isolation of three new trichothecane-type sesquiterpenoids, paecilomycines A-C (77-79) [55], two novel spirocyclic spirotenuipesines $A(80)$ and $B(81)$ [56], as well as tenuipesine $A(82)$, a novel trichothecane with an unprecedented carbon-migrated skeleton including a cyclopropane ring [57]. In addition, seven conventional trichothecenes (83-89) were also isolated [56]. These findings indicated that $P$. tenuipes was a rich source of novel trichothecanes. Two new diterpenoids, paecilomycines A (90) and B (91), including a novel skeleton with a five-membered lactone ring, together with three known labdane diterpenoids (92-94) were isolated from solid cultures of the insect pathogenic fungal strain Paecilomyces sp. ACCC
37762 [58]. The endophytic fungus Paecilomyces formosus LHL10 isolated from the roots of cucumber plants possesses significant inhibitory potential against urease and $\alpha$-glucosidase [59]. Subsequent chromatographic separation led to the isolation of a sesterterpenoid (95). Metabolite 95 was shown to have an unusual tricarbocyclic sesterterpenoid $\delta$-lactone skeleton [59]. Seven ergosterol derivatives (96-102) were isolated from silkworm larvae infected with Paecilomyces sp. 300 [60]. Stigmasterol (103), a phytosterol with a side chain containing ten carbon atoms attached at $\mathrm{C}-17$ to the steroid skeleton, was isolated from marine sponge-derived fungal isolates of Paecilomyces sp. [61].

\section{Peptides including diketopiperazines}

A new cyclohexadepsipeptide, paecilodepsipeptide A (104) ( $\triangleright$ Fig. 5), and its linear analogues paecilodepsipeptides B (105) and $C$ (106) were isolated from the insect pathogenic fungus Paecilomyces cinnamomeus BCC 9616 [62]. Compound 104 possessed a unique structural feature with three $D$-amino acid residues, including an unusual O-prenyl-D-Tyr, whereas it contained only one L-Ala. Its linear analogues 105 and 106 are hydrolysis and methanolysis products, which are considered artifacts formed during separation processes [62]. A new indolinepeptide (107) was isolated from silkworm larvae infected with Paecilomyces sp. J300 [63]. Three new macrocyclic tetralactams, gunnilactams A-C (108-110), were characterized from the submerged fermentation broth of $P$. gunnii, an entomogenous fungus identified as the 


$$
\text { (n) }
$$

104
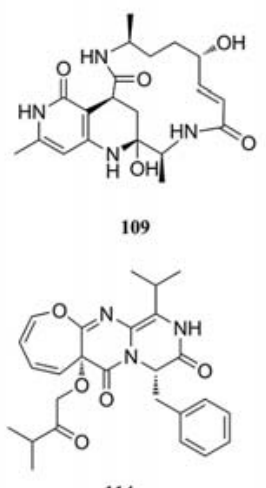

114

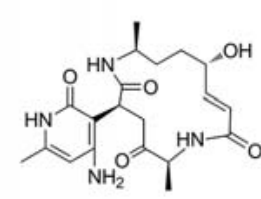

110

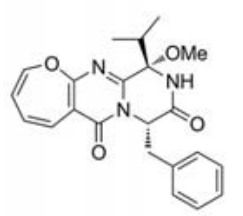

115

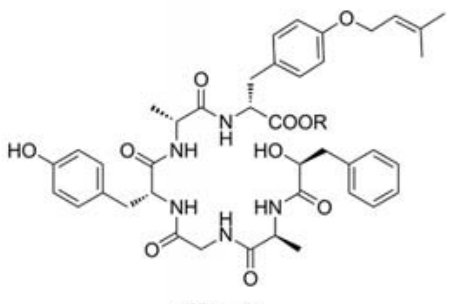

$105 \mathrm{R}=\mathrm{H}$

$106 \mathrm{R}=\mathrm{CH}_{3}$

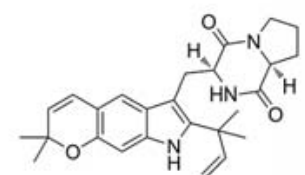

111

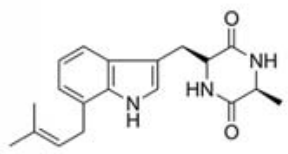

116<smiles>CC(NC(=O)[C@H](NC(=O)CNC(=O)O)C(C)(O)O)C(=O)N(C)C(=O)O</smiles>

107

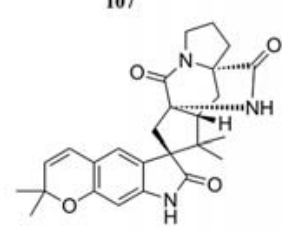

112

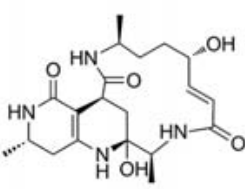

108

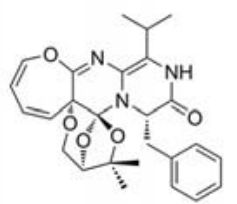

113

- Fig. 5 Peptides including diketopiperazines characterized from Paecilomyces species (104-116).

anamorph of Cordyceps gunnii [64]. Compounds 108-110 were novel macrocyclic tetralactams with an unusual skeleton produced by an undescribed biosynthesis pathway [64]. Two new prenylated indole alkaloids (111 and 112) were identified from the marine-derived fungus $P$. variotii EN-291, which was isolated as an endophyte from Grateloupia turuturu, a marine red alga collected from the coast of Qingdao, China [7]. These alkaloids often contained a diketopiperazine or a bicyclo[2.2.2]diazaoctane ring biogenetically derived from tryptophan. Unlike other related compounds, compounds 111 and 112 were rare examples of possessing dimethyl-substituted pyran rings coupled with indole moieties at C-5 and C-6 [7]. From the same fungal strain P. variotii EN-291, three new oxepine-containing diketopiperazines (113-115) were also characterized $[6,9]$. Varioxepine $A(113)$ represented a novel $3 \mathrm{H}$-oxepine-containing alkaloid characterized by a structurally unprecedented condensed 3,6,8-trioxabicyclo[3.2.1]octane motif [6]. The culture broth extract of the insect pathogen $P$. cinnamomeus BCC 9616 provided a known diketopiperazine, terezine D (116) [65].

\section{Alkaloids and other nitrogen-containing compounds}

A new pyridone alkaloid, militarinone A (117) ( $>$ Fig. 6), was identified by neuritogenic activity-guided fractionation from the mycelia of the entomogenous fungus Paecilomyces militaris RCEF 0095 [66]. Compound 117 featured an unprecedented side chain and a cis-(1,4-dihydroxycylohexyl) moiety formed by the condensation of phenylalanine and polyketide precursors. Subsequently, a new pyridone alkaloid, militarinone $\mathrm{D}$ (118), and two novel 3-acyl tetramic acids, militarinones B (119) and C (120), were obtained from this insect pathogenic fungus [67]. Compounds 119 and 120, having a pyrrolidin-2,4-dione ring and a conjugated side chain, were among the polyenoyltetramic acids occurring as red or yellow pigments in Penicillium and Streptomyces strains [67]. Interestingly, in solution, 3-acylated tetramic acids can form rapidly interchanging internal tautomers, and their NMR data may appear as distinct sets of signals. The NMR spectra of compounds 119 and 120 were also indicative of two exo- and endo-forms of tautomers [67]. To search for more structurally related compounds, other entomogenous fungal strains, P. farinosus RCEF 0101 and P. farinosus RCEF 0097, were chosen. Further chromatographic separation of the fungus RCEF 0101 afforded three additional pyridone alkaloids, farinosones A-C (121-123) [68]. Farinosones $A(121)$ and $B(122)$ were closely related to militarinones, while farinosone $C$ (123) was derived from the initial condensation step in the proposed biosynthetic pathway [68]. Chemical investigations of the fungus RCEF 0097 led to the isolation of a new pyridone alkaloid, (+)-N-deoxymilitarinone A (124), with a cyclohexyl moiety [68]. The marine fungus Paecilomyces sp. derived from the marine sponge was cultivated to produce a new nitrogen-containing compound, 125 [61]. Variotin (126) and three novel compounds, formosusins A-C (127-129), were isolated from cultures of the fungus $P$. formosus [69]. A large-scale culture of the marine mudflat-derived fungus $P$. formosus yielded a new pyrrolooxazine, formoxazine (130), a previously reported dipyrroloquinone derivative (131), and a 2-oxazolidinone analogue (132) [70]. Two maleimide-bearing compounds, including the new farinomalein (133), were identified from the fungus $P$. farinosus HF599 [70]. A new tetramic acid derivative, paecilosetin (135), was characterized from the fungus $P$. farinosus isolated from infected insect larvae [71]. Huperzine A (136), a naturally occurring alkaloid in the 


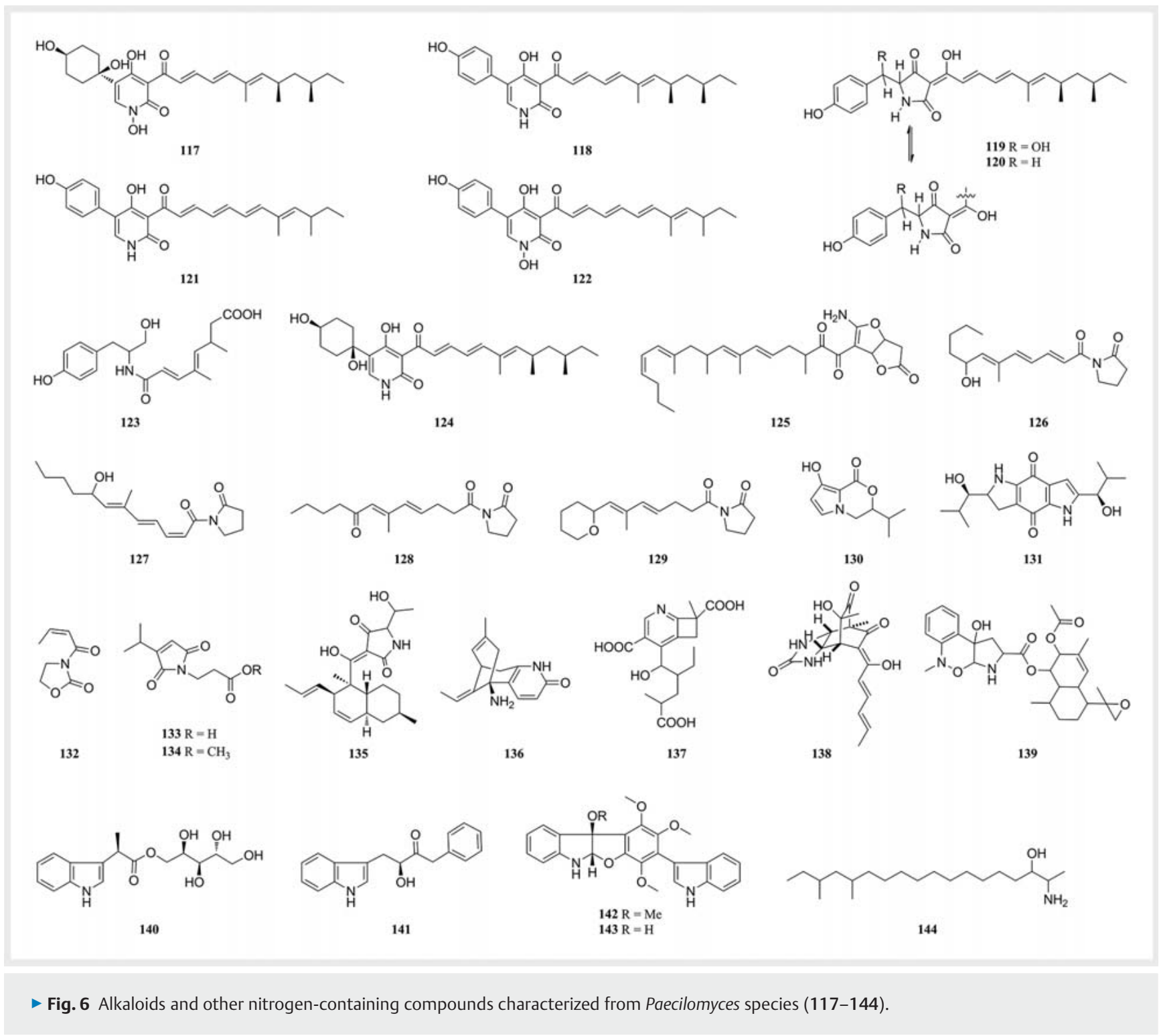

plant family Huperziaceae, was produced by Paecilomyces tenuis YS-13, an endophytic fungus isolated from Huperzia serrata [72]. A new pyridine (137) was isolated from the nematicidal active fungal strain of Paecilomyces sp. YMF1.01761 [73]. A ureido Diels-Alder adduct of sorbicillinol 138 was isolated from an intertidal marine Paecilomyces marquandii strain [74]. A novel nematicidal antibiotic, paeciloxazine (139), with a pyrrolobenzoxazine skeleton, was characterized from the culture broth of the fungus Paecilomyces sp. BAUA3058 strain [75]. An indole alkaloid acremoauxin A (140) was isolated from cultures of Paecilomyces sp. CAFT156, an endophytic fungus residing in $E$. chlorantha Oliv (Annonaceae) leaves [44]. Kurasoin B (141) was obtained from the cultured broth of Paecilomyces sp. FO-3684 [76]. Two cyclized bisindolyl benzenoid derivatives (142-143), including the new varioloid A (142), were isolated from the marine alga-derived endophytic fungus P. variotii EN-291 [10]. Finally, the amino alcohol compound paecilaminol (144) was isolated from the cultured broth of the fungus Paecilomyces sp. FKI-0550 [77].

\section{Shikimate-derived metabolites and lipids}

Bioassay-guided fractionation of the marine-derived endophytic fungus $P$. variotii EN-291 resulted in the isolation of two new butenolides, butyrolactone IX (145) and aspulvinone O (146) [7] ( $\vee$ Fig. 7). Finally, two new bicyclic fatty acids with a 6,8-dioxabicyclo[3.2.1] octane core skeleton, paecilonic acids A and B (147 and 148), were characterized from the marine fungus $P$. variotii derived from jellyfish [78].

\section{Biological Activities of Secondary Metabolites}

The producing strain, environment source, and biological activities of compounds 1-148 have been detailed in > Table 1. Anticancer, antimicrobial, and insecticidal activities were the three main indexes used to assess the pharmacological activity of these natural compounds. In this section, the detailed descriptions of compounds with potent biological activities are provided below. 


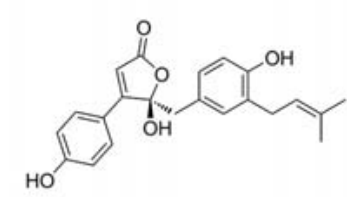

145

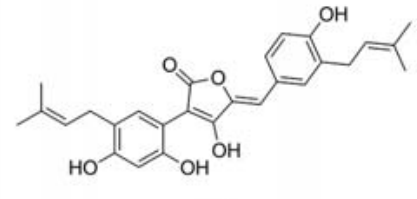

146

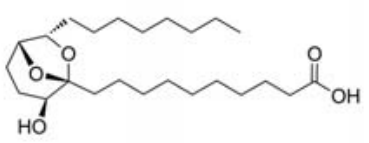

147

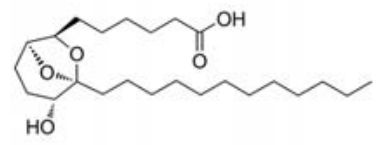

148

- Fig. 7 Shikimate-derived metabolites and lipids characterized from Paecilomyces species (145-148).

\section{Anticancer activity}

Brefeldin A (1) was found to show potent cytotoxicity against HL60, KB, HeLa, MCF-7, and Spc-A-1 cell lines with $\mathrm{IC}_{50}$ values ranging from 1 to $10 \mathrm{ng} / \mathrm{mL}$, which were close to or higher than those of Taxol. Therefore, brefeldin A is regarded as a very promising lead compound in cancer therapy [30]. The isolated new RALs were evaluated for their cytotoxicity against A549, HeLa, and MCF-7 tumor cells. In general, RALs with no bridging within the macrocycle, such as 20,22 , and 23 , exhibited promising cytotoxicity $\left(\mathrm{IC}_{50}<10 \mu \mathrm{M}\right)$ against at least one of the three tested cell lines, while the RALs featuring bridged macrolactones, such as 14-17 with a tetrahydrofuran ring, 18 and 19 with the $6 / 11 / 5$, and 21 with the 6/10/6 ring system, were almost inactive. Paeciloxanthone (31) was tested for cytotoxicity against HepG2 cell lines and showed significant activity with an $\mathrm{IC}_{50}$ value of $1.08 \mu \mathrm{g} / \mathrm{mL}$ [36]. Saintopin (34) and UCE1022 (35) showed cytotoxic activity against a human tumor cell line, HeLa S3, with $\mathrm{IC}_{50}$ values of 1.0 and $6.1 \mu \mathrm{M}$, respectively $[37,38]$. Paeciloxocin A (40) exhibited strong cytotoxicity against $\mathrm{HepG2}$ cells with an ${ }^{I} C_{50}$ value of $1 \mu \mathrm{g} / \mathrm{mL}$ [41]. Two $\alpha$-pyrones, pyrenocines A (64) and $B(65)$, showed potent cytotoxic activity against a human embryonic lung fibroblast cell line, MRC-5, with $\mathrm{IC}_{50}$ values of 0.38 and $0.98 \mu \mathrm{g} / \mathrm{mL}$, respectively [49]. Acetoxyscirpenediol (87) possessed potent cytotoxic activities against the human gastric tumor cell line (SNU-1), human hepatoma cell line (SNU-354), human colorectal tumor cell line (SNU-C4), and murine sarcoma180 with $\mathrm{IC}_{50} \mathrm{~S}$ of $1.2,4.0,2.2$, and $1.9 \mu \mathrm{M}$, respectively [79]. The cytotoxic effect of 87 was approximately 4.0-6.6 times stronger than that of cisplatin, which is currently used clinically for cancer patients [79]. The ergosterol derivatives (98-102) showed nonspecific moderate cytotoxicity against five human tumor cell lines [60]. The cyclic depsipeptide paecilodepsipeptide A (104) showed promising cytotoxicity toward two cancer cell lines, KB ( $\mathrm{IC}_{50}$ of $5.9 \mu \mathrm{M})$ and $B C\left({ }^{2} C_{50}\right.$ of $\left.6.6 \mu \mathrm{M}\right)$; however, its linear analogues 105 and 106 were inactive, indicating that the cyclic depsipeptide structure is necessary for its biological activities [62]. The macrocyclic tetralactam gunnilactam A (108) displayed selective inhibitory activity against $C 42 B$ cells with an $I C_{50}$ value of $5.4 \mu \mathrm{M}$ [64]. Prenylated indole alkaloids 111 and 112 showed weak cytotoxic activity against $\mathrm{NCl}-\mathrm{H} 460$ (human large cell lung carcinoma cell line) with $\mathrm{IC}_{50}$ values of 69.3 and $55.9 \mu \mathrm{M}$, respectively [8]. Paecilosetin (135) exhibited moderate activity against the murine leukemic P388 cell line with an $\mathrm{IC}_{50}$ value of $3.2 \mu \mathrm{g} / \mathrm{mL}$ [71]. Two cyclized bisindolyl benzenoid derivatives (142 and 143) exhibited cytotoxicity against A549, HCT116, and HepG2 cell lines with $I C_{50}$ values ranging from 2.6 to $8.2 \mu \mathrm{g} / \mathrm{mL}$ [10].

\section{Antimicrobial activity}

Of the RALs, paecilomycins G-I (11-13) and paecilomycin M (17) showed weak antifungal activity against the phytopathogenic fungus Peronophythora litchii, while compounds 22-24 exhibited moderate activity against $P$. litchii with $\mathrm{IC}_{50}$ values of 9.2, 41.0, and $19.3 \mu \mathrm{M}$, respectively [32,33]. Paeciloxocin A (40) inhibited the growth of Curvularia lunata (Walker) Boedijn and Candida albicans ATCC 10231 with inhibition zones of 12 and $10 \mathrm{~mm}$, respectively [41]. The dimeric octaketide spiroketal 51 showed modest antibacterial activity against the marine pathogen Vibrio ichthyoenteri [46]. Paecilocins B (56) and C (57) showed moderate antibacterial activity against Staphylococcus aureus SG 511 and methicillin-resistant S. aureus 3089 (MRSA) with MIC values ranging from 5 to $40 \mu \mathrm{g} / \mathrm{mL}$ [47]. Paecilospirone (71) showed antimicrobial activity against Bacillus subtilis with an MIC value of $5 \mu \mathrm{g} / \mathrm{mL}$ at $25^{\circ} \mathrm{C}$, but at $37^{\circ} \mathrm{C}, 71$ did not show any effect due to rapid destruction [51]. The new oxepine-containing diketopiperazines 113-115 exhibited potent antifungal activity against the plant-pathogenic fungus Fusarium graminearum with MIC values ranging from 4 to $8 \mu \mathrm{g} / \mathrm{mL}[6,9]$. Compound 125 moderately inhibited MRSA with an inhibition zone of $8 \mathrm{~mm}$ [61]. Compound 130 displayed antibacterial activity against MRSA and multidrugresistant S. aureus (MDRSA) with MICs of $6.25 \mu \mathrm{g} / \mathrm{mL}$ [70]. Farinomalein (133) significantly inhibited the plant pathogen Phytophthora sojae with an MIC value of $5 \mu \mathrm{g} /$ disk, whereas the MIC of the antifungal agent amphotericin B was $10 \mu \mathrm{g} /$ disk [80]. Paecilosetin (135) caused considerable growth inhibition of Bacillus subtilis and the pathogenic fungi Cladosporium resinae and Trichophyton mentagrophytes [71].

\section{Insecticidal activity}

Compounds 2-10 were evaluated for their antiplasmodial activity against the chloroquine-susceptible line Plasmodium falciparum 3D7 and the chloroquine-resistant line Dd2. The new compound paecilomycin $E(6)$ exhibited potent activity against 3D7 with an $I_{50}$ value of $20.0 \mathrm{nM}$, which was comparable to the positive controls artemisinin and chloroquine, while other compounds showed only moderate activity [31]. However, in the assay against the line Dd2, only compounds 3, 6, 7, and 9 exhibited moderate activity with $\mathrm{IC}_{50}$ values ranging from 1.7 to $10.5 \mu \mathrm{M}$ [31]. These findings implied RALs as models for the discovery of new antimalarial molecules. The new $\alpha$-pyrone pyrenocine I (63) showed 
- Table 1 The producing strain, environment source, and biological activities of 1-148.

\begin{tabular}{|c|c|c|c|c|}
\hline No. & Producing strain & Environment source & Biological activities & Reference \\
\hline 1 & Paecilomyces sp. & $\begin{array}{l}\text { Isolated as an endophyte from traditional } \\
\text { Chinese medical plants Taxus mairei and } \\
\text { Torreya grandis. }\end{array}$ & $\begin{array}{l}\text { Potent cytotoxicity against HL-60, KB, Hela, } \\
\text { MCF-7, and Spc-A- } 1 \text { cell lines. }\end{array}$ & {$[30]$} \\
\hline $2-10$ & Paecilomyces sp. SC0924 & $\begin{array}{l}\text { Isolated from a soil sample collected in } \\
\text { the Dinghu Mountain Biosphere Reserve, } \\
\text { Guangdong, China. }\end{array}$ & $\begin{array}{l}\text { Potent antiplasmodial activity against } \\
\text { Plasmodium falciparum lines. }\end{array}$ & {$[31]$} \\
\hline $11-13$ & Paecilomyces sp. SC0924 & $\begin{array}{l}\text { Isolated from a soil sample collected in } \\
\text { the Dinghu Mountain Biosphere Reserve, } \\
\text { Guangdong, China. }\end{array}$ & $\begin{array}{l}\text { Weak or no antifungal activity against } \\
\text { Peronophythora litchi. }\end{array}$ & {$[32]$} \\
\hline $14-17$ & Paecilomyces sp. SC0924 & $\begin{array}{l}\text { Isolated from a soil sample collected in } \\
\text { the Dinghu Mountain Biosphere Reserve, } \\
\text { Guangdong, China. }\end{array}$ & $\begin{array}{l}\text { Weak antifungal activity against } \\
\text { Peronophythora litchii. }\end{array}$ & {$[33]$} \\
\hline $18-25$ & Paecilomyces sp. SC0924 & $\begin{array}{l}\text { Isolated from a soil sample collected in } \\
\text { the Dinghu Mountain Biosphere Reserve, } \\
\text { Guangdong, China. }\end{array}$ & $\begin{array}{l}\text { Either cytotoxic against MCF-7, A549, } \\
\text { and HeLa cells or antifungal activity against } \\
\text { Peronophythora litchi. }\end{array}$ & {$[34]$} \\
\hline $26-30$ & P. carneus P-177 & $\begin{array}{l}\text { Isolated from a soil sample collected in a } \\
\text { jungle region of Bolivia. }\end{array}$ & $\begin{array}{l}\text { Potent inhibitory activity against protein } \\
\text { tyrosine kinase in the micromolar range. }\end{array}$ & {$[35]$} \\
\hline $31-33$ & Paecilomyces sp. & $\begin{array}{l}\text { Isolated from an estuarine mangrove } \\
\text { from the Taiwan Strait. }\end{array}$ & $\begin{array}{l}\text { Cytotoxicity against HepG2; acetylcholines- } \\
\text { terase inhibitory and antimicrobial activities. }\end{array}$ & {$[36]$} \\
\hline 34 & Paecilomyces sp. & $\begin{array}{l}\text { Isolated from soil collected at a vineyard } \\
\text { in Yamanashi Prefecture, Japan. }\end{array}$ & $\begin{array}{l}\text { Topoisomerase II-dependent DNA cleavage } \\
\text { activity, weak antimicrobial activity against } \\
\text { gram-positive bacteria, and potent cytotoxic } \\
\text { activity against HeLa S3. }\end{array}$ & {$[38]$} \\
\hline 35 & $\begin{array}{l}\text { Paecilomyces UOE1022 } \\
\text { (FERM BP-4066). }\end{array}$ & $\begin{array}{l}\text { Isolated from soil collected in Koganei city, } \\
\text { Tokyo, Japan. }\end{array}$ & $\begin{array}{l}\text { Topoisomerase I mediated DNA cleavage ac- } \\
\text { tivity and cytotoxic activity against HeLa S3. }\end{array}$ & {$[37]$} \\
\hline 36,37 & Paecilomyces sp. & $\begin{array}{l}\text { Isolated as an endophyte from mangrove } \\
\text { bark from Xiamen. }\end{array}$ & No obvious cytotoxic activity. & {$[39]$} \\
\hline 38,39 & P. variotii & $\begin{array}{l}\text { Isolated from an egg gallery of mountain } \\
\text { pine beetle in lodgepole pine at Invermere, } \\
\text { British Columbia. }\end{array}$ & Weak antibacterial activity. & {$[40]$} \\
\hline 40,41 & Paecilomyces sp. & $\begin{array}{l}\text { Isolated from the saprophytic bark } \\
\text { of mangrove from the Taiwan Strait. }\end{array}$ & $\begin{array}{l}\text { Significant cytotoxicity against HepG } 2 \text { and } \\
\text { antimicrobial activity. }\end{array}$ & {$[41]$} \\
\hline 42,43 & Paecilomyces sp. 3193B & Source not given. & $\begin{array}{l}\text { Moderate to potent inhibitory activity } \\
\text { against AGE formation. }\end{array}$ & {$[42]$} \\
\hline $44-46$ & P. gunnii & Source not given. & Strong tyrosinase inhibitory activity. & {$[43]$} \\
\hline 47,140 & Paecilomyces sp. CAFT156 & $\begin{array}{l}\text { Isolated as an endophyte from leaves } \\
\text { of Enantia chlorantha Oliv. }\end{array}$ & $\begin{array}{l}\text { Weak antibacterial activity and moderate } \\
\text { cytotoxicity towards brine shrimp larvae } \\
\text { (Artemia salina). }\end{array}$ & {$[44]$} \\
\hline $48-49$ & Paecilomyces sp. SC0924 & $\begin{array}{l}\text { Isolated from a soil sample collected in } \\
\text { the Dinghu Mountain Biosphere Reserve, } \\
\text { Guangdong, China. }\end{array}$ & No obvious bioactivity. & {$[31]$} \\
\hline 50 & Paecilomyces sp. & $\begin{array}{l}\text { Isolated from the coral reef at Yap Island, } \\
\text { Federated States of Micronesia. }\end{array}$ & No obvious bioactivity. & {$[45]$} \\
\hline $51-54$ & P. variotii J08NF-1 & $\begin{array}{l}\text { Isolated from the jellyfish Nemopilema } \\
\text { nomurai collected off the southern coast } \\
\text { of Korea. }\end{array}$ & $\begin{array}{l}\text { Modest antibacterial activity against the } \\
\text { marine pathogen Vibrio ichthyoenteri. }\end{array}$ & {$[46]$} \\
\hline $55-58$ & P. variotii & $\begin{array}{l}\text { Isolated from the jellyfish Nemopilema } \\
\text { nomurai collected off the southern coast } \\
\text { of Korea. }\end{array}$ & $\begin{array}{l}\text { Moderate antibacterial activity against } \\
\text { methicillin-resistant Staphylococcus aureus. }\end{array}$ & {$[47]$} \\
\hline $59-62$ & P. lilacinus (J04J-1) F-9 & $\begin{array}{l}\text { Isolated from a marine sponge Petrosia sp. } \\
\text { collected from Jeju Island, South Korea. }\end{array}$ & No obvious cytotoxicity. & {$[48]$} \\
\hline $63-66$ & Paecilomyces sp. FKI-3573 & $\begin{array}{l}\text { Isolated from a soil sample collected in Hilo, } \\
\text { HI, USA. }\end{array}$ & $\begin{array}{l}\text { Potent antitrypanosomal activity against Try- } \\
\text { panosoma brucei brucei and cytotoxic activity. }\end{array}$ & {$[49]$} \\
\hline $67-70,76$ & $\begin{array}{l}\text { P. cateniobliquus } \\
\text { YMF1.01799 }\end{array}$ & Source not given. & $\begin{array}{l}\text { Significant inhibitory effect on the growth of } \\
\text { cotton bollworm Helicoverpa armigera. }\end{array}$ & $\begin{array}{l}\text { [50] } \\
\text { continu }\end{array}$ \\
\hline
\end{tabular}


- Table 1 Continued

\begin{tabular}{|c|c|c|c|c|}
\hline No. & Producing strain & Environment source & Biological activities & Reference \\
\hline 71 & Paecilomyces sp. & $\begin{array}{l}\text { Isolated from a soil sample collected } \\
\text { in Takatsuki City. }\end{array}$ & Antimicrobial activity against Bacillus subtilis. & {$[51]$} \\
\hline 72 & Paecilomyces cf. javanica & $\begin{array}{l}\text { Isolated from the marine sponge Jaspis cf. } \\
\text { Coriacea }\end{array}$ & No obvious cytotoxicity. & {$[52]$} \\
\hline 73 & P. variotii Bain & Source not given. & No biological activity tested. & [53] \\
\hline 74,75 & $\begin{array}{l}\text { P. variotii Bainier SANK } \\
21086\end{array}$ & Source not given. & $\begin{array}{l}\text { High herbicidal activity against broadleaf } \\
\text { weeds and selectivity to corn. }\end{array}$ & {$[54]$} \\
\hline $77-79$ & P. tenuipes & Source not given. & $\begin{array}{l}\text { Potent neurotrophic factor biosynthesis } \\
\text { activity in glial cells. }\end{array}$ & [55] \\
\hline $\begin{array}{l}80,81 \\
83-89\end{array}$ & P. tenuipes & Source not given. & $\begin{array}{l}\text { Potent neurotrophic factor biosynthesis } \\
\text { activity in glial cells. }\end{array}$ & {$[56]$} \\
\hline 82 & P. tenuipes & Source not given. & No biological activity tested. & [57] \\
\hline $90-94$ & $\begin{array}{l}\text { Paecilomyces sp. ACCC } \\
37762\end{array}$ & $\begin{array}{l}\text { Isolated from an unidentified Lepidopteran } \\
\text { collected in Hebei Province, China. }\end{array}$ & No biological activity tested. & {$[58]$} \\
\hline 95 & P. formosus LHL10 & Isolated from the root of a cucumber plant. & $\begin{array}{l}\text { Remarkable enzymes inhibitory activity } \\
\text { against } \alpha \text {-glucosidase and urease. }\end{array}$ & [59] \\
\hline $96-102$ & Paecilomyces sp. J300 & Source not given. & $\begin{array}{l}\text { Moderate cytotoxicity against five tumor } \\
\text { cells. }\end{array}$ & {$[60]$} \\
\hline 103,125 & Paecilomyces sp. & $\begin{array}{l}\text { Isolated from the marine sponge collected } \\
\text { along Tinggi Island, Malaysia. }\end{array}$ & $\begin{array}{l}\text { Moderate antimicrobial activity against } \\
\text { MRSA. }\end{array}$ & {$[61]$} \\
\hline 104-106 & P. cinnamomeus BCC 9616 & $\begin{array}{l}\text { Isolated from a Homoptera scale insect } \\
\text { collected in Thailand. }\end{array}$ & $\begin{array}{l}\text { Antimalarial activity against the malarial } \\
\text { parasite Plasmodium falciparum K1 and cyto- } \\
\text { toxicity toward two cancer cell lines. }\end{array}$ & [62] \\
\hline 107 & Paecilomyces sp. J300 & Source not given. & No biological activity tested. & [63] \\
\hline $108-110$ & P. gunnii & Source not given. & $\begin{array}{l}\text { Selective cytotoxic activity against human } \\
\text { prostate cancer } C 42 B \text { cells. }\end{array}$ & {$[64]$} \\
\hline 111,112 & P. variotii EN-291 & $\begin{array}{l}\text { Isolated from a marine red alga Grateloupia } \\
\text { turuturu collected from the coast of } \\
\text { Qingdao, China. }\end{array}$ & Weak cytotoxic activity against $\mathrm{NCl}-\mathrm{H} 460$. & [7] \\
\hline 113 & P. variotii EN-291 & $\begin{array}{l}\text { Isolated from a marine red alga Grateloupia } \\
\text { turuturu. }\end{array}$ & $\begin{array}{l}\text { Potent antifungal activity against plant } \\
\text { pathogenic fungus Fusarium graminearum. }\end{array}$ & [6] \\
\hline 114,115 & P. variotii EN-291 & $\begin{array}{l}\text { Isolated from a marine red alga Grateloupia } \\
\text { turuturu. }\end{array}$ & $\begin{array}{l}\text { Potent antifungal activity against Fusarium } \\
\text { graminearum. }\end{array}$ & [9] \\
\hline 116 & P. cinnamomeus BCC 9616 & $\begin{array}{l}\text { Isolated from a Homoptera scale insect } \\
\text { collected in Thailand. }\end{array}$ & No biological activity tested. & {$[65]$} \\
\hline 117 & P. militaris RCEF 0095 & $\begin{array}{l}\text { Isolated from a Lepidopteran pupa } \\
\text { collected in Anhui province, China. }\end{array}$ & $\begin{array}{l}\text { Pronounced neurotrophic effect in PC-12 } \\
\text { cells. }\end{array}$ & {$[66]$} \\
\hline $118-120$ & P. militaris RCEF 0095 & $\begin{array}{l}\text { Isolated from a Lepidopteran pupa } \\
\text { collected in Anhui province, China. }\end{array}$ & Weak neuritogenic activity in PC- 12 cells. & [67] \\
\hline $121-123$ & P. farinosus RCEF 0101 & $\begin{array}{l}\text { Isolated from an unidentified Lepidopteran } \\
\text { collected in Anhui Province, China. }\end{array}$ & $\begin{array}{l}\text { Considerable neuritogenic activity in PC-12 } \\
\text { cells. }\end{array}$ & [68] \\
\hline 124 & P. farinosus RCEF 0097 & $\begin{array}{l}\text { Isolated from a Lepidopteran species } \\
\text { collected in Yunnan Province, China. }\end{array}$ & $\begin{array}{l}\text { Induced neurite sprouting in PC- } 12 \text { cells } \\
\text { when tested at } 33 \text { and } 100 \mu \mathrm{M} \text { concentra- } \\
\text { tions. }\end{array}$ & {$[80]$} \\
\hline $126-129$ & P. formosus & Isolated from the seaside in Japan. & $\begin{array}{l}\text { Inhibited the activity of mammalian DNA } \\
\text { polymerase } \beta \text {. }\end{array}$ & [69] \\
\hline $130-132$ & P. formosus & $\begin{array}{l}\text { Isolated from the marine mudflat collected } \\
\text { at Suncheon Bay, Korea. }\end{array}$ & $\begin{array}{l}\text { Antibacterial activity against MRSA and } \\
\text { MDRSA, and potent radical-scavenging } \\
\text { activity against DPPH. }\end{array}$ & [70] \\
\hline 133,134 & P. farinosus HF599 & $\begin{array}{l}\text { Isolated from a Lepidopteran larval cadaver } \\
\text { collected on Mt. Tsukuba, Ibaraki, Japan. }\end{array}$ & $\begin{array}{l}\text { Potent antifungal activity against the plant } \\
\text { pathogenic Phytophthora sojae. }\end{array}$ & {$[70]$} \\
\hline 135 & P. farinosus & $\begin{array}{l}\text { Isolated from an infected insect larva from } \\
\text { leaf litter collected from a suburban garden } \\
\text { in New Zealand. }\end{array}$ & $\begin{array}{l}\text { Moderate to weak cytotoxic activity against } \\
\text { the P388 cell line and antimicrobial activity. }\end{array}$ & [71] \\
\hline
\end{tabular}

continued 
- Table 1 Continued

\begin{tabular}{|c|c|c|c|c|}
\hline No. & Producing strain & Environment source & Biological activities & Reference \\
\hline 136 & P. tenuis YS-13 & $\begin{array}{l}\text { Isolated as an endophyte from Huperzia } \\
\text { serrata. }\end{array}$ & No biological activity tested. & [72] \\
\hline 137 & $\begin{array}{l}\text { Paecilomyces sp. } \\
\text { YMF1.01761 }\end{array}$ & Isolated from soil in Yunnan Province, China. & $\begin{array}{l}\text { Nematicidal activity against Bursaphelenchus } \\
\text { xylophilus and Meloidogyne arenaria. }\end{array}$ & [73] \\
\hline 138 & P. marquandii BAFC 486 & $\begin{array}{l}\text { Isolated from an intertidal marine sediment } \\
\text { sample. }\end{array}$ & No biological activity tested. & [74] \\
\hline 139 & Paecilomyces sp. BAUA3058 & $\begin{array}{l}\text { Isolated from a soil sample collected in } \\
\text { Ibaraki Prefecture, Japan. }\end{array}$ & $\begin{array}{l}\text { Moderate nematicidal and insecticidal } \\
\text { activity against Plutella xylostella. }\end{array}$ & [75] \\
\hline 141 & Paecilomyces sp. FO-36841 & $\begin{array}{l}\text { Isolated from a soil sample collected in } \\
\text { Kurashiki City, Japan. }\end{array}$ & $\begin{array}{l}\text { Moderate activity in inhibiting protein } \\
\text { farnesyltransferase. }\end{array}$ & [76] \\
\hline 142,143 & P. variotii EN-291 & $\begin{array}{l}\text { Isolated from Grateloupia turuturu, a marine } \\
\text { red alga collected from the coast of } \\
\text { Qingdao, China. }\end{array}$ & $\begin{array}{l}\text { Cytotoxicity against A549, HCT116, } \\
\text { and HepG2 cell lines. }\end{array}$ & [10] \\
\hline 144 & Paecilomyces sp. FKI-0550 & $\begin{array}{l}\text { Isolated from a soil sample collected on } \\
\text { Miyakojima Island, Okinawa Prefecture, } \\
\text { Japan. }\end{array}$ & $\begin{array}{l}\text { Inhibitory activity against NADH-fumarate } \\
\text { reductase. }\end{array}$ & [77] \\
\hline 145,146 & P. variotii EN-291 & $\begin{array}{l}\text { Isolated from Grateloupia turuturu, a marine } \\
\text { red alga collected from the coast of } \\
\text { Qingdao, China. }\end{array}$ & Potent DPPH radical scavenging activity. & [7] \\
\hline 147,148 & P. variotii & $\begin{array}{l}\text { Isolated from the inner tissues of the jelly- } \\
\text { fish Nemopilema nomurai. }\end{array}$ & No biological activity tested. & [78] \\
\hline
\end{tabular}

a similar antitrypanosomal activity against Trypanosoma brucei (IC 50 of $1.8 \mu \mathrm{g} / \mathrm{mL}$ ) compared to the commonly used drug suramin, while pyrenocine $A(64)$ showed the most potent activity with an $\mathrm{IC}_{50}$ value of $0.12 \mu \mathrm{g} / \mathrm{mL}$ [49]. The polyketide-derived compound 69 showed a significant inhibitory effect on the overall growth of the cotton bollworm Helicoverpa armigera, while surprisingly, the terpenoid-derived metabolite 76 significantly promoted the growth of the larvae, revealing that $P$. cateniobliquus could produce diverse metabolites to regulate the growth of the insect [50]. The cyclic depsipeptide paecilodepsipeptide A (104) exhibited activity against the malarial parasite $P$. falciparum $\mathrm{K} 1$ with an $\mathrm{IC}_{50}$ value of $4.9 \mu \mathrm{M}$ [62]. The new pyridine 137 displayed nematicidal activity against Bursaphelenchus xylophilus, Meloidogyne arenaria, and Panagrellus redivivus with $L_{50}$ values of 167.7, 47.1, and $50.86 \mathrm{mg} / \mathrm{L}$, respectively [73]. Pyrolobenzoxazine 139 showed moderate nematicidal activity against Rhabditis pseudoelongata and insecticidal activity against Culex pipiens pallens [75].

\section{Enzyme inhibitory activity}

The novel anthraquinones (26-30) significantly inhibited the epidermal growth factor receptor protein tyrosine kinase (PTK) in the micromolar range. Two metabolites, 26 and 28, were proven to be potent and selective inhibitors of v-abl PTK with an $\mathrm{IC}_{50}$ value of $0.4 \mu \mathrm{M}$ [35]. The new xanthone paeciloxanthone (31) displayed acetylcholinesterase inhibition activity in vitro with an $\mathrm{IC}_{50}$ value of $2.25 \mu \mathrm{g} / \mathrm{mL}$ [36]. Saintopin (34) possessed topoisomerase IIdependent DNA cleavage activity, while UCE1022 (35) selectively inhibited the breakage-rejoining reaction of topoisomerase I by stabilizing a cleavable complex $[37,38]$. The three new phenalenones paecilomycones A-C (44-46) exhibited strong tyrosinase inhibitory activity with $\mathrm{IC}_{50} \mathrm{~s}$ of $0.11,0.17$, and $0.14 \mathrm{mM}$, respec- tively, which were equal to or higher than those of the positive controls kojic acid $(0.10 \mathrm{mM})$ and arbutin $(0.20 \mathrm{mM})$ [43]. The enzyme inhibition bioassay indicated that sesterterpenoid 95 exhibited remarkable inhibition against $\alpha$-glucosidase and urease with $I_{50}$ values of 61.80 and $74.25 \mu \mathrm{g} / \mathrm{g}$, respectively [59]. Formosusins B (127), a new cis-olefin analog of compound 126 , selectively inhibited the activity of mammalian DNA polymerase $\beta$ in vitro, with an $\mathrm{IC}_{50}$ of $35.6 \mu \mathrm{M}$, while other compounds were inactive [69]. Kurasoin B (141) moderately inhibited protein farnesyltransferase in a dose-dependent manner [76]. The amino alcohol 144 exhibited an $\mathrm{IC}_{50}$ value of $5.1 \mu \mathrm{M}$ against Ascaris suum NADH-fumarate reductase [77].

\section{Neuritogenic activity}

Paecilomycin A (77) showed potent activity in neurotrophic factor biosynthesis in glial cells, which was 1000 times higher than that of scabronine G [55]. Trichothecanes 80 and 81 were also active in neurotrophic factor biosynthesis [56]. The isolation of trichothecane-type sesquiterpenoids indicated that these compounds probably had potential as lead compounds for neurodegenerative diseases such as Alzheimer's disease [55,56]. The new pyridone alkaloid 117 was evaluated for its potential to stimulate neuronal differentiation of PC-12 cells and found to induce a pronounced neurotrophic effect [66]. However, in contrast to 117, structurally related compounds $118-120$ showed only negligible neurotrophic activity in PC-12 cells [67]. Compounds 121 and 123 also induced neurite outgrowth in the PC-12 cell line at a concentration of $50 \mu \mathrm{M}$, while compound 122 was inactive [68]. Compound 124 induced neurite sprouting in PC-12 cells when tested at concentrations of 33 and $100 \mu \mathrm{M}$. The neurotrophic effect of 124 is thus weaker than that of militarinone A (117) [81]. 


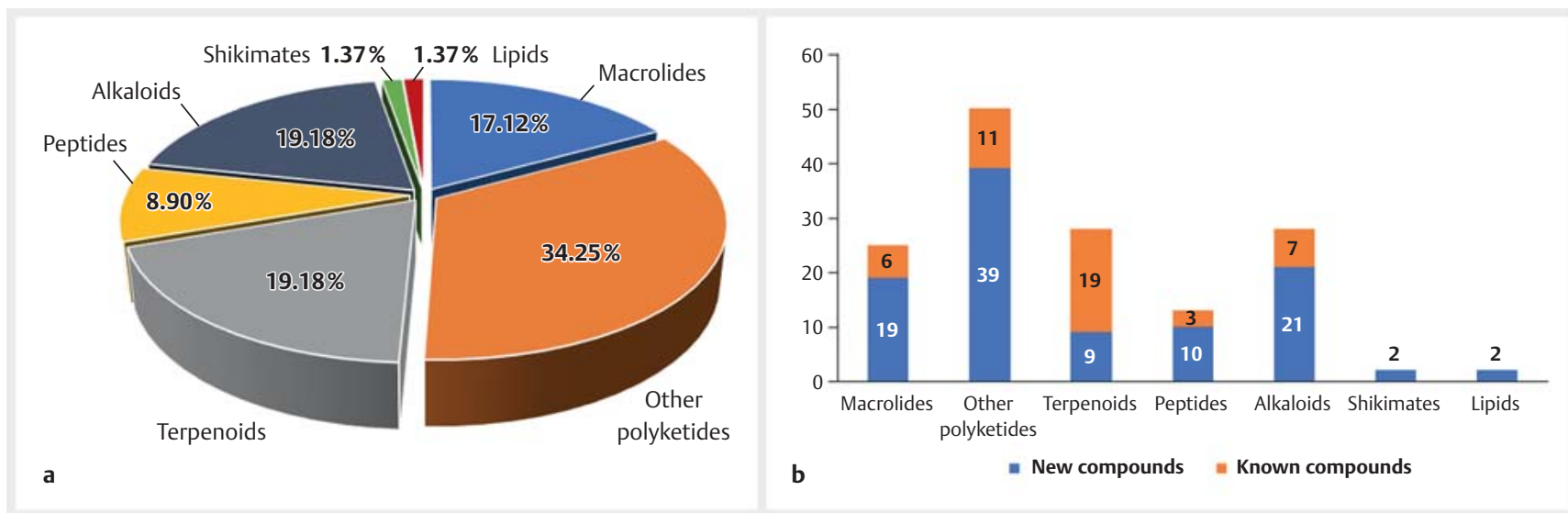

- Fig. 8 a Percentage of distribution of compounds from Paecilomyces species based on their putative biogenetic origin. b New compounds produced by Paecilomyces species.

\section{Other bioactivities}

4-O-Demethylsilvaticol (42) and (-)-mitorubrin (43), isolated as Maillard reaction inhibitors, showed potent inhibitory activity against cross-linked protein formation and AGE formation [42]. Both compounds possessed a 1,3-dihydroxybenzene moiety that might contribute to trapping methylglyoxal in the formation of AGEs. Paeciloside A (47) displayed moderate cytotoxicity toward brine shrimp larvae (Artemia salina) with a mortality rate of $31 \%$ at a concentration of $10 \mu \mathrm{g} / \mathrm{mL}$ [44]. 14-Hydroxycornexistin (75) possessed high herbicidal activity against weeds and low phytotoxicity to corn, suggesting that other nonadrides may be of interest for evaluation as potential herbicides [54]. Compounds 130 and 132 displayed potent radical scavenging activity against DPPH with $\mathrm{IC}_{50}$ values of 0.1 and $10 \mu \mathrm{M}$, respectively, which were 200 times higher than that of the positive control ascorbic acid $\left(\mathrm{IC}_{50}\right.$ of $\left.20 \mu \mathrm{M}\right)$ [70]. Butenolide 146 displayed potent DPPH radical scavenging activity with an $\mathrm{IC}_{50}$ value of $11.6 \mu \mathrm{M}$, which was stronger than that of the positive control BHT (butylated hydroxytoluene) (with an $\mathrm{IC}_{50}$ of $\left.117.7 \mu \mathrm{M}\right)$ [7].

\section{Conclusions and Future Perspectives}

Species from the Paecilomyces genus are capable of producing a variety of secondary metabolites with diverse chemical classes and biological activities. They have emerged as a treasure house for finding novel pharmaceutical and/or agrochemical lead compounds. Fig. 8 summarizes the structural/biogenetic types of the 148 chemical structures isolated from Paecilomyces species. Based on their putative biogenetic origin, these metabolites were classified into polyketides (including macrolides) (1-25 for macrolides and 26-75 for other polyketides), terpenoids and steroids (76-103), peptides including diketopiperazines (104-116), alkaloids and other nitrogen-containing compounds (117-144), and shikimate-derived metabolites and lipids (145-148). It should be pointed out that in most cases, the classification of a certain metabolite depends only on structural considerations just represents the individual judgment of the authors. The structural classification of secondary metabolites according to biogenetic categories is to some degree arbitrary, since a number of compounds derive from mixed biogenesis, such as PKS-NRPS (PKS: polyketide synthases; NRPS: nonribosomal peptide synthetases) hybrids and miscellaneous nitrogenated derivatives. For example, paecilomycone $\mathrm{C}(45)$ contains an $\mathrm{NH}_{2}$ group in its structure and hence can be considered a nitrogen-containing compound. Herein, however, we categorize it as a polyketide based on the biosynthetic origin of phenalenones. As evident from $>$ Fig. 8, among the 148 metabolites observed, approximately $51 \%$ were polyketide derived. We specifically list macrolides as an individual group, since this kind of compound constitutes $17.1 \%$ of the metabolites reported, nearly as many as terpenoids and alkaloids. Moreover, among the 25 macrolides reported, 19 compounds were described as new macrolides ( $\bullet$ Fig. 8 b). Taking other polyketides into account, the number of new compounds is up to 58. These findings indicate that Paecilomyces species are promising producing strains of novel polyketides.

As mentioned above, the taxonomic classification of Paecilomyces species was ill-defined due to their similar morphological characteristics and insufficient molecular identification. To the best of our knowledge, a total of 45 fungal strains have been reported as producing the described secondary metabolites. However, most of them were unable to be adequately identified. Only 13 strains, including $P$. carneus, $P$. cateniobliquus, $P$. cinnamomeus, $P$. farinosus, P. formosus, P. gunnii, P. javanica, P. lilacinus, P. marquandii, P. militaris, $P$. tenuipes, $P$. tenuis, and $P$. variotii, had absolutely determined phylogenetic positions ( $\triangleright$ Fig. 9). Among them, P. variotii was the most prolific in producing strains, with 22 metabolites identified from this species. The fungus $P$. variotii is well known for its metabolic potential to produce abundant bioactive secondary metabolites. Our chemical studies of $P$. variotii EN-291, an endophytic fungus isolated from the red alga $G$. turuturu, led to the identification of three new oxepine-containing alkaloids (113-115) with antimicrobial activity [6,9], two new butenolide derivatives (145 and 146) with DPPH radical scavenging activity [7], two new prenylated indole alkaloids (111 and 112) with cytotoxic activity [8], and a new cyclized bisindolyl benzenoid derivative (142) with cytotoxic activity [10]. Following $P$. variotii, $P$. tenuipes was also a very promising source of producing strains, with 13 novel trichothecane-type sesquiterpenoids characterized [55-57]. The unidenti- 


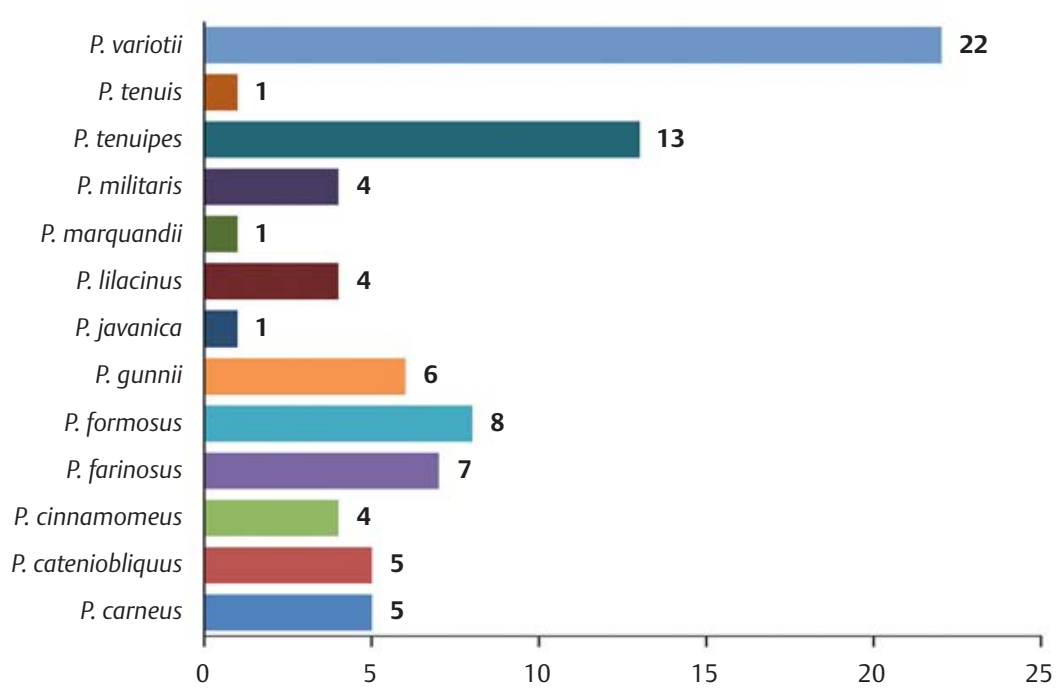

- Fig. 9 Compounds characterized from different producing strains.

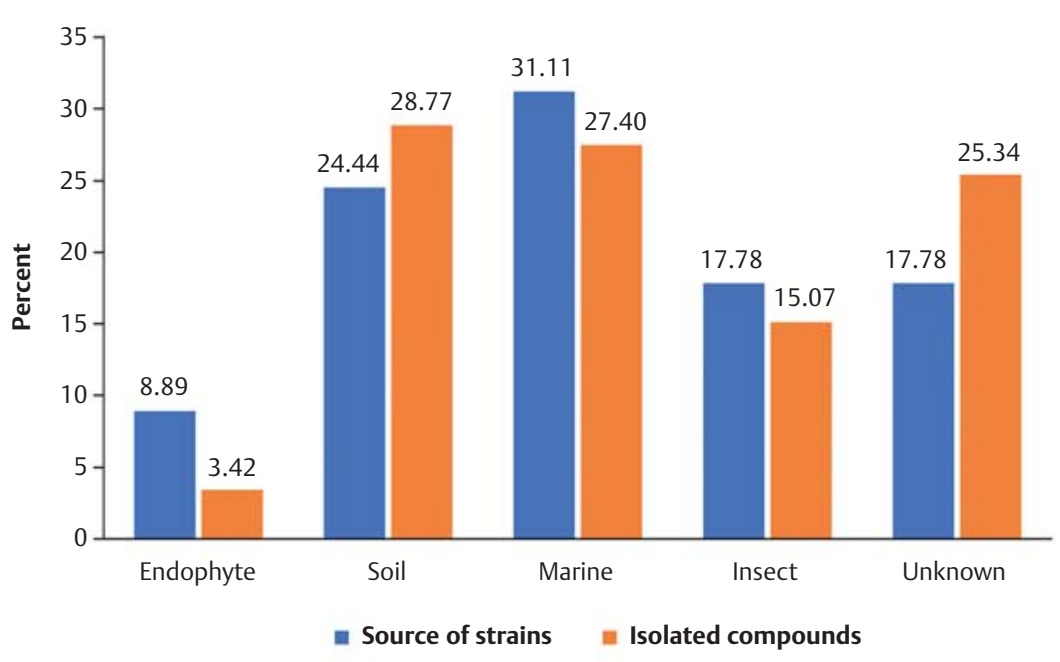

- Fig. 10 Percentage of distribution of producing strains and isolated compounds from different sources.

fied strains not only confounded the phylogenetic positions within this species but also hampered the use of diagnostic chemical markers to distinguish them from a chemotaxonomy point of view.

Paecilomyces species are widely distributed and commonly occur in air, compost, and various foodstuffs. The distribution of these fungal communities reported for chemical research is shown in $>$ Fig. 10. It can be estimated that $31 \%$ of these producing strains were isolated from marine environments, with approximately $27 \%$ of the compounds characterized. Producing strains can be isolated from a vast range of marine habitats, such as nonliving marine sediments and mudflats, marine invertebrates (including sponges, corals, and jellyfish), and marine plants (algae and mangroves). The fungal strains isolated from a marine envi- ronment were usually cultured in natural or artificial seawater with a certain salinity (ranging from 50 to $100 \%$ ), while those from a terrestrial environment were cultured in distilled water. It is believed that the different cultural manner may affect the richness of the secondary metabolites. In a hyperhaline environment, the fungal strains may produce more structurally diverse metabolites to induce resistance to high salt stress. Soil is also an important source of these fungal strains. As summarized in $>$ Fig. 10, nearly $24 \%$ of the 45 producing strains and $28 \%$ of the reported compounds come from soil. Other strains are also isolated as endophytes from medicinal plants or isolated from insects. Although a small sample cannot yield statistically significant conclusions, it appears that the marine environment and soil are better sources of these strains than others. Therefore, further studies should be 


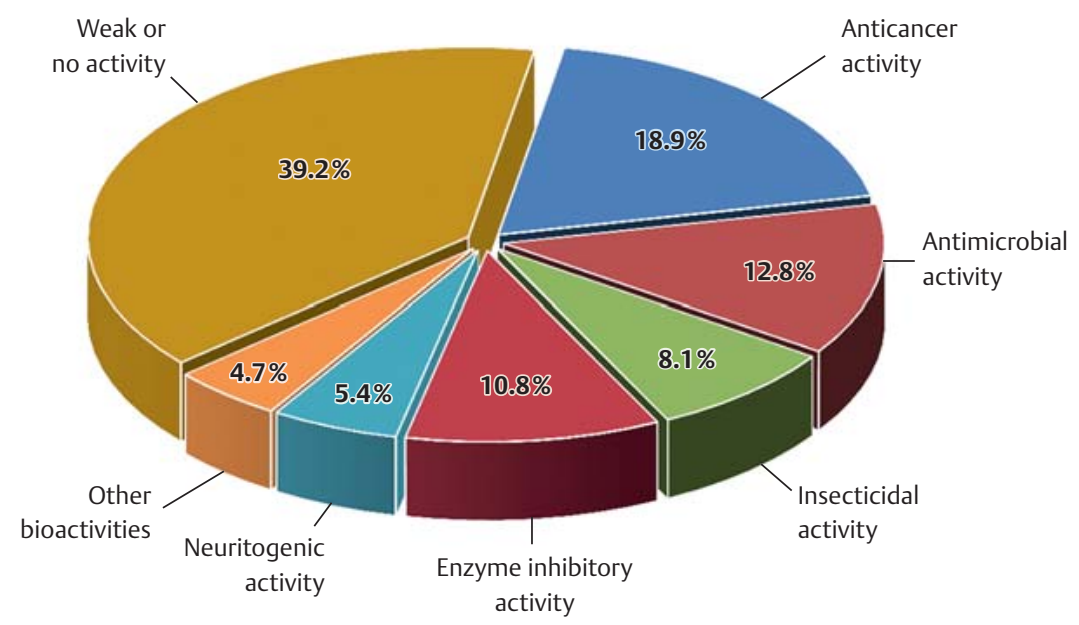

- Fig. 11 Bioactivity categories of the reported metabolites.

particularly focused on the marine environment and soil as potential sources to search for more producing strains.

These secondary metabolites not only possess intriguing structures but also exhibit a variety of biological activities, including anticancer, antimicrobial, insecticidal, enzyme inhibitory, and neuritogenic activities ( $\triangleright$ Fig. 11). Among the 148 metabolites presented in this review, an extraordinarily high proportion $(60.8 \%)$ of the isolated metabolites showed moderate to potent activities. Most importantly, some of the compounds showed potent (or significant) activities compared to those of the positive controls (usually commercial medicines), which indicates that they could be used as potential alternatives to traditional drugs. These include the anticancer lead compound acetoxyscirpenediol (87), the antimicrobial farinomalein (133), the antiplasmodial paecilomycin $E(6)$, and the tyrosinase inhibitors paecilomycones A-C (44-46). Acetoxyscirpenediol (87) showed potent cytotoxicities against SNU-1, SNU-354, SNU-C4, and murine sarcoma-180 with $\mathrm{IC}_{50}$ values of $1.2,4.0,2.2$, and $1.9 \mu \mathrm{M}$, respectively [79]. The cytotoxic effect of 87 was 4.0-6.6 times stronger than that of cisplatin, a strong and widely used chemotherapy drug for cancer patients [79]. Farinomalein (133) showed potent antifungal effects on the plant pathogen $P$. sojae with an MIC value of $5 \mu \mathrm{g} /$ disk, whereas the MIC of the antifungal agent amphotericin B was $10 \mu \mathrm{g} /$ disk [80]. Paecilomycin E (6) exhibited potent antiplasmodial activity against $P$. falciparum $3 \mathrm{D} 7$ with an $\mathrm{IC}_{50}$ value of $20.0 \mathrm{nM}$, which was equal to that of the positive controls artemisinin and chloroquine [31]. Paecilomycones A-C (44-46) exhibited strong tyrosinase inhibitory activity with $\mathrm{IC}_{50}$ values of $0.11,0.17$, and $0.14 \mathrm{mM}$, respectively, which were equal to or higher than those of the positive controls kojic acid $(0.10 \mathrm{mM})$ and arbutin (0.20 mM) [43]. Paecilomycin A (77) showed potent activity in neurotrophic factor biosynthesis, 1000 times higher than that of scabronine $G$ [55]. These remarkable activities make many of these compounds suitable candidates for new drug discovery and may lead to future synthesis studies.
Overall, Paecilomyces species possess great potential for their applications as biocontrol agents. This species is considered to be a rich and innovative source for exploring lead compounds with medicinal and/or agricultural importance. Chemical studies of these fungal strains have led to the characterization of 148 bioactive metabolites. Among them, some compounds showed potent activities that are expected to be beneficial for the development of new medicines and agrochemicals in the near future.

\section{Supporting information}

Phylogenetic analyses of Paecilomyces species using ITS rDNA and $\beta$-tubulin genes are available as Supporting Information.

\section{Contributors' Statement}

Drafting the manuscript: X.Q. Li, K. Xu; design of the review: P. Zhang, X.M. Liu; critical revision of the manuscript: P. Zhang, K. Xu.

\section{Acknowledgements}

This work was supported by the National Natural Science Foundation of China (31700295 and 81803375) and the Agricultural Science and Technology Innovation Program of China (ASTIP-TRIC05).

\section{Conflict of Interest}

The authors declare that they have no conflict of interest.

\section{References}

[1] Bainier G. Mycothèque de l'école de Pharmacie. XI. Paecilomyces, genre nouveau de Mucédinées. Bull Soc Mycol Fr 1907; 23: 26-27

[2] Luangsa-Ard J], Hywel-Jones NL, Samson RA. The polyphyletic nature of Paecilomyces sensu lato based on 18S-generated rDNA phylogeny. Mycologia 2004; 96: 773-780

[3] Frisvad JC. Taxonomy, chemodiversity, and chemoconsistency of Aspergillus, Penicillium, and Talaromyces species. Front Microbiol 2014; 5: 773 
[4] Mioso R, Toledo Marante FJT, de Laguna IH. The chemical diversity of the Ascomycete fungus Paecilomyces variotii. Appl Biochem Biotechnol 2015; 177: 781-791

[5] Zimmermann G. The entomopathogenic fungi Isaria farinose (formerly Paecilomyces farinosus) and the Isaria fumosorosea species complex (formerly Paecilomyces fumosoroseus): biology, ecology and use in biological control. Biocontrol Sci Technol 2008; 18: 865-901

[6] Zhang P, Mándi A, Li XM, Du FY, Wang JN, Li X, Kurtán T, Wang BG. Varioxepine $\mathrm{A}$, a $3 \mathrm{H}$-oxepine-containing alkaloid with a new oxa-cage from the marine algal-derived endophytic fungus Paecilomyces variotii. Org Lett 2014; 16: 4834-4837

[7] Zhang P, Li XM, Wang JN, Li X, Wang BG. New butenolide derivatives from the marine-derived fungus Paecilomyces variotii with DPPH radical scavenging activity. Phytochem Lett 2015; 11: 85-88

[8] Zhang P, Li XM, Wang JN, Li X, Wang BG. Prenylated indole alkaloids from the marine-derived fungus Paecilomyces variotii. Chin Chem Lett 2015; 26: 313-316

[9] Zhang P, Li XM, Wang JN, Wang BG. Oxepine-containing diketopiperazine alkaloids from the algal-derived endophytic fungus Paecilomyces variotii EN-291. Helv Chim Acta 2015; 98: 800-804

[10] Zhang P, Li XM, Mao XX, Mándi A, Kurtán T, Wang BG. Varioloid A, a new indolyl-6,10b-dihydro-5aH-[1]benzofuro[2,3-b]indole derivative from the marine alga-derived endophytic fungus Paecilomyces variotii EN-291. Beilstein J Org Chem 2016; 12: 2012-2018

[11] Chang HT, Lin MH, Hwang IH, Chen T], Lin HC, Hou MC, Hwang SJ. Scientific publications in gastroenterology and hepatology in Taiwan: An analysis of Web of Science from 1993 to 2013. J Chin Med Assoc 2017; 80: 80-85

[12] Samson RA. Paecilomyces and some allied Hyphomycetes. Stud Mycol 1974; 6: 1-119

[13] Inglis PW, Tigano MS, Biology M. Identification and taxonomy of some entomopathogenic Paecilomyces spp. (Ascomycota) isolates using rDNA-ITS sequences. Genet Mol Biol 2006; 29: 132-136

[14] Oborník M, Jirku M, Dolezel D. Phylogeny of mitosporic entomopathogenic fungi: is the genus Paecilomyces polyphyletic? Can J Microbiol 2001; 47: 813-819

[15] Luangsa-ard J], Hywel-Jones NL, Manoch L, Samson RA. On the relationships of Paecilomyces sect. Isarioidea species. Mycol Res 2005; 109: $581-$ 589

[16] Gams W, Hodge KT, Samson RA, Korf RP, Seifert KA. (1684) Proposal to conserve the name Isaria (anamorphic fungi) with a conserved type. Taxon 2005; 54 : 537

[17] Hodge KT, Gams W, Samson RA, Korf RP, Seifert KA. Lectotypification and status of Isaria pers.: fr. Taxon 2005; 54: 485-489

[18] Cho YJ, Hwang HJ, Kim SW, Song CH, Yun JW. Effect of carbon source and aeration rate on broth rheology and fungal morphology during red pigment production by Paecilomyces sinclairii in a batch bioreactor. J Biotechnol 2002; 95: 13-23

[19] Wang L, Li Y, Yu P, Xie Z, Luo Y, Lin Y. Biodegradation of phenol at high concentration by a novel fungal strain Paecilomyces variotii JH6. J Hazard Mater 2010; 183: 366-371

[20] Madeira JV jr., Macedo JA, Macedo GA. Detoxification of castor bean residues and the simultaneous production of tannase and phytase by solid-state fermentation using Paecilomyces variotii. Bioresour Technol 2011; 102: 7343-7348

[21] Atkins SD, Clark IM, Pande S, Hirsch PR, Kerry BR. The use of real-time PCR and species-specific primers for the identification and monitoring of Paecilomyces lilacinus. FEMS Microbiol Ecol 2005; 51: 257-264

[22] Lara J, Acosta N, Betancourt C, Vincente N, Rodríguez R. Biological control of Meloidogyne incognita in tomato in Puerto Rico. Nematropica 1996; 26: 143-152
[23] Kiewnick S, Sikora RA. Biological control of the root-knot nematode Meloidogyne incognita by Paecilomyces lilacinus strain 251. Biol Control 2006; 38: 179-187

[24] Yang F, Abdelnabby H, Xiao Y. A mutant of the nematophagous fungus Paecilomyces lilacinus (Thom) is a novel biocontrol agent for Sclerotinia sclerotiorum. Microb Pathog 2015; 89: 169-176

[25] Wraight SP, Carruthers RI, Jaronski ST, Bradley CA, Garza C], GalainiWraight S. Evaluation of the entomopathogenic fungi Beauveria bassiana and Paecilomyces fumosoroseus for microbial control of the silverleaf whitefly, Bemisia argentifolii. Biol Control 2000; 17: 203-217

[26] Asaff A, Cerda-Garcia-Rojas C, de la Torre M. Isolation of dipicolinic acid as an insecticidal toxin from Paecilomyces fumosoroseus. Appl Microbiol Biotechnol 2005; 68: 542-547

[27] Kavková M, Čurn V. Paecilomyces fumosoroseus (Deuteromycotina: Hyphomycetes) as a potential mycoparasite on Sphaerotheca fuliginea (Ascomycotina: Erysiphales). Mycopathologia 2005; 159: 53-63

[28] Han JH, Jin BR, Kim J], Lee SY. Virulence of entomopathogenic fungi Metarhizium anisopliae and Paecilomyces fumosoroseus for the microbial control of Spodoptera exigua. Mycobiology 2014; 42: 385-390

[29] Betina V. Biological effects of the antibiotic brefeldin A (decumbin, cyanein, ascotoxin, synergisidin): a retrospective. Folia Microbiol 1992; 37: 3-11

[30] Wang J, Huang Y, Fang M, Zhang Y, Zheng Z, Zhao Y, Su W. Brefeldin A, a cytotoxin produced by Paecilomyces sp. and Aspergillus clavatus isolated from Taxus mairei and Torreya grandis. FEMS Immunol Med Microbiol 2002; 34: 51-57

[31] Xu L, He Z, Xue J, Chen X, Wei X. $\beta$-Resorcylic acid lactones from a Paecilomyces fungus. J Nat Prod 2010; 73: 885-889

[32] Xu L, Xue J, Zou Y, He S, Wei X. Three new $\beta$-resorcylic acid lactones from Paecilomyces sp. SC0924. Chin J Chem 2012; 30: 1273-1277

[33] Xu LX, Wu P, Wei HH, Xue JH, Hu XP, Wei XY. Paecilomycins J-M, fou new $\beta$-resorcylic acid lactones from Paecilomyces sp. SC0924. Tetrahedron Lett 2013; 54: 2648-2650

[34] Xu L, Wu P, Xue J, Molnar I, Wei X. Antifungal and cytotoxic $\beta$-resorcylic acid lactones from a Paecilomyces species. J Nat Prod 2017; 80: 22152223

[35] Petersen F, Fredenhagen A, Mett $H$, Lydon NB, Delmendo R, Jenny $H B$, Peter $\mathrm{H}$. Paeciloquinones $\mathrm{A}, \mathrm{B}, \mathrm{C}, \mathrm{D}, \mathrm{E}$ and $\mathrm{F}$ : new potent inhibitors of protein tyrosine kinases produced by Paecilomyces carneus. J Antibiot 1995; 48: 191-198

[36] Wen L, Lin YC, She ZG, Du DS, Chan WL, Zheng ZH. Paeciloxanthone, a new cytotoxic xanthone from the marine mangrove fungus Paecilomyces sp. (Tree1-7). J Asian Nat Prod Res 2008; 10: 133-137

[37] Fujii N, Yamashita Y, Ando K, Agatsuma T, Saitoh Y, Gomi K, Nishiie Y, Nakano H. UCE1022, a new antitumor antibiotic with topoisomerase mediated DNA cleavage activity, from Paecilomyces. J Antibiot 1994; 47: 949-951

[38] Yamashita Y, Saitoh Y, Ando K, Takahashi K, Ohno H, Nakano H. Saintopin, a new antitumor antibiotic with topoisomerase II dependent DNA cleavage activity, from Paecilomyces. J Antibiot 1990; 43: 1344-1346

[39] Guo Z, She Z, Shao C, Wen L, Liu F, Zheng Z, Lin Y. 1H and 13C NMR signal assignments of paecilin $A$ and $B$, two new chromone derivatives from mangrove endophytic fungus Paecilomyces sp. (tree 1-7). Magn Reson Chem 2007; 45: 777-780

[40] Ayer WA, Craw PA, Nozawa KJ. Two $1 \mathrm{H}$-naphtho[2,3-c]pyran-1-one metabolites from the fungus Paecilomyces variotii. Can J Chen 1991; 69: 189-191

[41] Wen L, Chen G, She Z, Yan C, Cai J, Mu L. Two new paeciloxocins from a mangrove endophytic fungus Paecilomyces sp. Russ Chem Bull 2010; 59 : 1656-1659

[42] Li D, Shigetomi K, Mitsuhashi S, Ubukata M. Maillard reaction inhibitors produced by Paecilomyces sp. Biosci Biotechnol Biochem 2013; 77: 2499-2501 
[43] Lu R, Liu X, Gao S, Zhang W, Peng F, Hu F, Huang B, Chen L, Bao G, Li C, Li Z. New tyrosinase inhibitors from Paecilomyces gunnii. J Agric Food Chem 2014; 62: 11917-11923

[44] Talontsi FM, Nwemeguela Kenla TJ, Dittrich B, Douanla-Meli C, Laatsch H. Paeciloside A, a new antimicrobial and cytotoxic polyketide from Paecilomyces sp. strain CAFT156. Planta Med 2012; 78: 1020-1023

[45] Namikoshi M, Kobayashi H, Yoshimoto T, Meguro S. Paecilospirone, a unique spiro[chroman-2, $1 \mathrm{~V}^{\prime}\left(3^{\prime} H\right)$-isobenzofuran] derivative isolated from tropical marine fungus Paecilomyces sp. Chem Lett 2000; 29: 308309

[46] Wang H, Hong J, Yin J, Moon HR, Liu Y, Wei X, Oh DC, Jung JH. Dimeric octaketide spiroketals from the jellyfish-derived fungus Paecilomyces variotii j08NF-1. J Nat Prod 2015; 78: 2832-2836

[47] Liu J, Li F, Kim EL, Li JL, Hong J, Bae KS, Chung HY, Kim HS, Jung JH. Antibacterial polyketides from the jellyfish-derived fungus Paecilomyces variotii. J Nat Prod 2011; 74: 1826-1829

[48] Elbandy M, Shinde PB, Hong JK, Bae KS, Kim M, Lee SM, Jung J. $\alpha$-Pyrones and yellow pigments from the sponge-derived fungus Paecilomyces lilacinus. Bull Korean Chem Soc 2009; 30: 188-192

[49] Hashida J, Niitsuma M, Iwatsuki M, Mori M, Ishiyama A, Namatame M, Nishihara-Tsukashima A, Nonaka K, Ui H, Masuma R, Otoguro K, Yamada $\mathrm{H}$, Shiomi K, Omura S. Pyrenocine I, a new pyrenocine analog produced by Paecilomyces sp. FKI-3573. J Antibiot (Tokyo) 2010; 63: 559-561

[50] Wu HY, Wang YL, Tan JL, Zhu CY, Li DX, Huang R, Zhang KQ, Niu XM. Regulation of the growth of cotton bollworms by metabolites from an entomopathogenic fungus Paecilomyces cateniobliquus. J Agric Food Chem 2012; 60: 5604-5608

[51] Hirota A, Nakagawa M, Hirota H. Structure of paecilospirone, a new antibiotic from Paecilomyces. Agric Biol Chem 1991; 55: 1187-1188

[52] Rahbæk L, Sperry S, Piper JE, Crews PJ. Deoxynortrichoharzin, a new polyketide from the saltwater culture of a sponge-derived Paecilomyces fungus. J Nat Prod 1998; 61: 1571-1573

[53] Aldridge DC, Carman RM, Richard B. A new tricarboxylic acid anhydride from Paecilomyces variotii. J Chem Soc Perkin Trans 1; 1980: 2134-2135

[54] Fields S, Mireles-Lo L, Gerwick B. Hydroxycornexistin: a new phytotoxin from Paecilomyces variotii. J Nat Prod 1996; 59: 698-700

[55] Kikuchi H, Miyagawa Y, Sahashi Y, Inatomi S, Haganuma A, Nakahata N, Oshima Y. Novel trichothecanes, paecilomycine A, B, and C, isolated from entomopathogenic fungus, Paecilomyces tenuipes. Tetrahedron Lett 2004; 45: 6225-6228

[56] Kikuchi H, Miyagawa Y, Sahashi Y, Inatomi S, Haganuma A, Nakahata N, Oshima Y. Novel spirocyclic trichothecanes, spirotenuipesine A and B, isolated from entomopathogenic fungus, Paecilomyces tenuipes. J Org Chem 2004; 69: 352-356

[57] Kikuchi H, Miyagawa Y, Nakamura K, Sahashi Y, Inatomi S, Oshima Y. A novel carbon skeletal trichothecane, tenuipesine $A$, isolated from an entomopathogenic fungus, Paecilomyces tenuipes. Org Lett 2004; 6: $4531-4533$

[58] Zhou K, Zhao XL, Han LP, Cao MM, Chen C, Shi BZ, Luo D. Paecilomycines $A$ and $B$, novel diterpenoids, isolated from insect-pathogenic fungi Paecilomyces sp. ACCC 37762. Helv Chim Acta 2015; 98: 642-649

[59] Bilal S, Ali L, Khan AL, Shahzad R, Asaf S, Imran M, Kang SM, Kim SK, Lee IJ. Endophytic fungus Paecilomyces formosus LHL10 produces sesterterpenoid YW3548 and cyclic peptide that inhibit urease and $\alpha$-glucosidase enzyme activities. Arch Microbiol 2018; 200: 1493-1502

[60] Kwon HC, Zee SD, Cho SY, Choi SU, Lee KR. Cytotoxic ergosterols from Paecilomyces sp. J300. Arch Pharm Res 2002; 25: 851-855

[61] Mosadeghzad Z, Zuriati Z, Asmat A, Gires U, Wickneswari R, Pittayakhajonwut P, Farahani G. Chemical components and bioactivity of the marine-derived fungus Paecilomyces sp. Collected from Tinggi Island, Malaysia. Chem Nat Compd 2013; 49: 621-625
[62] Isaka M, Palasarn S, Kocharin K, Nigel L. Comparison of the bioactive secondary metabolites from the scale insect pathogens, anamorph Paecilomyces cinnamomeus, and teleomorph Torrubiella luteorostrata. J Antibiot 2007; 60: 577-581

[63] Kwon HC, Kim KR, Zee SD, Cho SY, Lee K. A new indolinepeptide from Paecilomyces sp. J300. Arch Pharm Res 2004; 27: 604

[64] Zheng Y, Zhang J, Wei L, Shi M, Wang J, Huang J. Gunnilactams A-C, macrocyclic tetralactams from the mycelial culture of the entomogenous fungus Paecilomyces gunnii. J Nat Prod 2017; 80: 1935-1938

[65] Isaka M, Palasarn S, Lapanun S, Sriklung K. Paecilodepsipeptide A, an antimalarial and antitumor cyclohexadepsipeptide from the insect pathogenic fungus Paecilomyces cinnamomeus BCC 9616. J Nat Prod 2007; 70: $675-678$

[66] Schmidt K, Günther W, Stoyanova S, Schubert B, Li Z, Hamburger M. Militarinone A, a neurotrophic pyridone alkaloid from Paecilomyces militaris. Org Lett 2002; 4: 197-199

[67] Schmidt K, Riese U, Li Z, Hamburger M. Novel tetramic acids and pyridone alkaloids, militarinones $B, C$, and $D$, from the insect pathogenic fungus Paecilomyces militaris. J Nat Prod 2003; 66: 378-383

[68] Cheng Y, Schneider B, Riese U, Schubert B, Li Z, Hamburger M. Farinosones $\mathrm{A}-\mathrm{C}$, neurotrophic alkaloidal metabolites from the entomogenous deuteromycete Paecilomyces farinosus. J Nat Prod 2004; 67: 1854-1858

[69] Mizushina Y, Suzuki-Fukudome H, Takeuchi T, Takemoto K, Kuriyama I, Yoshida H, Kamisuki S, Sugawara F. Formosusin A, a novel specific inhibitor of mammalian DNA polymerase $\beta$ from the fungus Paecilomyces formosus. Bioorg Med Chem 2014; 22: 1070-1076

[70] Yun K, Leutou AS, Rho JR, Son BW. Formoxazine, a new pyrrolooxazine, and two amines from the marine-mudflat-derived fungus Paecilomyces formosus. Bull Korean Chem Soc 2016; 37: 103-104

[71] Lang G, Blunt JW, Cummings NJ, Cole AL, Munro M. Paecilosetin, a new bioactive fungal metabolite from a New Zealand isolate of Paecilomyces farinosus. J Nat Prod 2005; 68: 810-811

[72] Su J, Yang M. Huperzine A production by Paecilomyces tenuis YS-13, an endophytic fungus isolated from Huperzia serrata. Nat Prod Res 2015; 29: $1035-1041$

[73] Liu Y], Zhai CY, Liu Y, Zhang KQ. Nematicidal activity of Paecilomyces spp. and isolation of a novel active compound. J Microbiol 2009; 47: 248-252

[74] Cabrera GM, Butler M, Rodriguez MA, Godeas A, Haddad R, Eberlin M. A sorbicillinoid urea from an intertidal Paecilomyces marquandii. J Nat Prod 2006; 69: 1806-1808

[75] Kanai Y, Fujimaki T, Kochi S, Konno H, Kanazawa S, Tokumasu S. Paeciloxazine, a novel nematicidal antibiotic from Paecilomyces sp. J Antibiot 2004; 57: 24-28

[76] Uchida R, Shiomi K, Inokoshi ], Masuma R, Kawakubo T, Tanaka H, Iwai Y, Omura S. Kurasoins $A$ and $B$, new protein farnesyltransferase inhibitors produced by Paecilomyces sp. FO-3684. J Antibiot 1996; 49: 932-934

[77] Ui H, Shiomi K, Suzuki H, Hatano H, Morimoto H, Yamaguchi Y, Masuma R, Sakamoto K, Kita K, Miyoshi H. Paecilaminol, a new NADH-fumarate reductase inhibitor, produced by Paecilomyces sp. FKI-0550. J Antibiot 2006; 59: 591-596

[78] Wang $\mathrm{H}$, Hong J, Yin J, Liu J, Liu Y, Choi JS, Jung JH. Paecilonic acids A and $B$, bicyclic fatty acids from the jellyfish-derived fungus Paecilomyces variotii J08NF-1. Bioorg Med Chem Lett 2016; 26: 2220-2223

[79] Nam KS, Jo YS, Kim YH, Hyun JW, Kim H. Cytotoxic activities of acetoxyscirpenediol and ergosterol peroxide from Paecilomyces tenuipes. Life Sci 2001; 69: 229-237

[80] Putri SP, Kinoshita H, Ihara F, Igarashi Y, Nihira T. Farinomalein, a maleimide-bearing compound from the entomopathogenic fungus Paecilomyces farinosus. J Nat Prod 2009; 72: 1544-1546

[81] Cheng Y, Schneider B, Riese U, Schubert B, Li Z, Hamburger M. (+)-N-Deoxymilitarinone $A$, a neuritogenic pyridone alkaloid from the insect pathogenic fungus Paecilomyces farinosus. J Nat Prod 2006; 69: 436-438 